\title{
A Novel Depsidone and Some New Xanthones from Garcinia Species ${ }^{1)}$
}

\author{
Chihiro Ito, ${ }^{*, a}$ Yoshiaki Miyamoto, ${ }^{a}$ Minako Nakayama,,${ }^{a}$ Yuko KawaI, ${ }^{a}$ \\ K. Sundar RaO, ${ }^{b}$ and Hiroshi FurukaWA ${ }^{a}$ \\ Faculty of Pharmacy, Meijo University, ${ }^{a}$ Tempaku, Nagoya 468, Japan and National Research Centre for Environmental \\ Toxicology, ${ }^{b}$ The University of Queensland, 39 Kessels Road, Coopers Plains, QLD 4108, Australia. \\ Received March 14, 1997; accepted May 30, 1997
}

\begin{abstract}
Constituents of three EtOH extracts of the stem bark of Garcinia assigu LANTB., Garcinia dulcis (RoxB.) Kurz., and Garcinia latissima MıQ., belonging to the Guttiferae, collected in Central Province of Papua New Guinea, were studied. A novel depsidone named garcinisidone-A (1), six new xanthones named assiguxanthone-A (3) and -B (9) and dulxanthone-A (4), - B (6), - C (7), and -D (11), and four new pyranoxanthones named latisxanthone-A (13), -B (14), -C (15), and -D (16) were isolated, as well as some known xanthone, benzophenone, chromone, and biflavanone derivatives, and their structures were elucidated by spectroscopic methods. Among these components, garcinisidone-A (1) is the first example of a depsidone derivative having a five-carbon unit (prenyl) as a substituent to be found in nature. Latisxanthone-B (14) was found to contain a hydroperoxy moiety in the molecule. This is the second example of a xanthone hydroperoxide to be found in nature.
\end{abstract}

Key words Garcinia; depsidone; xanthone; hydroperoxide; pyranoxanthone; Guttiferae

In our previous paper ${ }^{2)}$ on biologically active natural products from Papua New Guinea medicinal plants, the isolation and structural elucidation of a novel dibenzofuran named calophyfuran, and two new xanthones named pancixanthone-A and -B from Calophyllum panciflorum A. C. SMIth were described. In our further studies on this project, three ethanolic extracts of the stem bark of Garcinia assigu LantB., Garcinia dulcis (RoxB.) KURZ., and Garcinia latissima MiQ., belonging to the Guttiferae, were found to exhibit antibacterial activity. ${ }^{3,4)}$ This paper describes the isolation and structural elucidation of a novel depsidone (11H-dibenzo $[b, e][1,4]$ dioxepin-11-one derivative) named garcinisidone-A (1) and two new xanthones named assiguxanthone-A (3) and -B (9) from G. assigu, four new xanthones named dulxanthone-A (4), -B (6), -C (7), and -D (11) from G. dulcis, and four new pyranoxanthones named latisxanthone-A (13), -B (14), -C (15) and -D (16) from G. latissima.

\section{Results and Discussion}

The dried stem barks of G. assigu, G. dulcis, and $G$. latissima were each extracted with EtOH under reflux. The hexane-, $\mathrm{CH}_{2} \mathrm{Cl}_{2}$, and EtOAc-soluble portions of each EtOH extract were fractionated by a combination of silica gel column chromatography and preparative TLC to give a novel depsidone, six new xanthones, and four new pyranoxanthones along with some known xanthone, benzophenone, chromone, and biflavanone derivatives.

Structure of Garcinisidone-A (1) Garcinisidone-A (1) was obtained as a pale yellow oil, and the molecular formula was determined as $\mathrm{C}_{24} \mathrm{H}_{26} \mathrm{O}_{7}$ by high-resolution mass spectrometry (HR-MS). The IR spectrum showed absorption bands due to hydroxyl groups and a lactone carbonyl group at $v_{\max } 3527,3300$ (br) and 1668, $1267 \mathrm{~cm}^{-1}$, respectively. The ${ }^{1} \mathrm{H}$ - and ${ }^{13} \mathrm{C}$-NMR spectra (Table 1) coupled with the results of ${ }^{1} \mathrm{H}$-detected heteronuclear multiple quantum coherence (HMQC) showed signals assignable to an $O$-methyl group $\left[\delta_{\mathrm{H}} 3.66(3 \mathrm{H}, \mathrm{s})\right.$; $\left.\delta_{\mathrm{C}} 60.05(\mathrm{q})\right]$, a lactone carbonyl group [ $\delta_{\mathrm{C}} 167.17$ (s)], two $1 \mathrm{H}$-singlets $\left[\delta_{\mathrm{H}} 6.26,6.65\right]$, and a hydroxyl group $\left[\delta_{\mathrm{H}}\right.$

* To whom correspondence should be addressed. $9.80(\mathrm{br})]$. Observations of two sets of signals $\left[\delta_{\mathrm{H}} 3.14\right.$ $(2 \mathrm{H}, \mathrm{d}, J=7.0 \mathrm{~Hz}) ; \delta_{\mathrm{C}} 21.43(\mathrm{t}), \delta_{\mathrm{H}} 5.10(1 \mathrm{H}, \mathrm{m}) ; \delta_{\mathrm{C}} 122.31$ $(\mathrm{d}), \delta_{\mathrm{C}} 130.48(\mathrm{~s}), \delta_{\mathrm{H}} 1.67(3 \mathrm{H}, \mathrm{s}) ; \delta_{\mathrm{C}} 17.66(\mathrm{q}), \delta_{\mathrm{H}} 1.58$ $(3 \mathrm{H}, \mathrm{s}) ; \delta_{\mathrm{C}} 25.42(\mathrm{q})$ and $\delta_{\mathrm{H}} 3.33(2 \mathrm{H}, \mathrm{d}, J=7.0 \mathrm{~Hz}) ; \delta_{\mathrm{C}}$ $23.48(\mathrm{t}), \delta_{\mathrm{H}} 5.08(1 \mathrm{H}, \mathrm{m}) ; \delta_{\mathrm{C}} 121.83(\mathrm{~d}), \delta_{\mathrm{C}} 131.64(\mathrm{~s}), \delta_{\mathrm{H}}$ $\left.1.74(3 \mathrm{H}, \mathrm{s}) ; \delta_{\mathrm{C}} 17.76(\mathrm{q}), \delta_{\mathrm{H}} 1.62(3 \mathrm{H}, \mathrm{s}) ; \delta_{\mathrm{C}} 25.46(\mathrm{q})\right]$ indicated the presence of two prenyl side chains in the molecule. Mass fragment ions at $m / z 370\left[\mathrm{M}^{+}-\cdot \mathrm{CH}=\right.$ $\left.\mathrm{C}\left(\mathrm{CH}_{3}\right)_{2}-\cdot \mathrm{H}\right]$ and $315\left[\mathrm{M}^{+}-\cdot \mathrm{CH}=\mathrm{C}\left(\mathrm{CH}_{3}\right)_{2}-\cdot \mathrm{CH}=\right.$ $\left.\mathrm{C}\left(\mathrm{CH}_{3}\right)_{2}-\cdot \mathrm{H}\right]$ in the electron impact (EI)-MS also suggested the presence of two prenyl side chains. $O$ Methylation with methyl iodide in acetone in the presence of anhydrous potassium carbonate gave a trimethylated derivative (2), suggesting the presence of three phenolic hydroxyl groups in the original molecule. The partial structures $a$ and $b$ of 1 (Chart 1) were confirmed by ${ }^{1} \mathrm{H}$-detected heteronuclear multiple bond connectivity (HMBC) spectroscopy, as shown by arrows in Fig. 1. The linked arrangement of the two moieties $(a$ and $b$ ) was elucidated from the following spectral data. a) An IR absorption due to a lactone carbonyl group at $v_{\max }$ $1668 \mathrm{~cm}^{-1}$ on 1 was observed at $v_{\max } 1730 \mathrm{~cm}^{-1}$ on 2, suggesting the presence of an intramolecular hydrogenbond in the original molecule. b) The carbon signals at $\delta_{\mathrm{C}}$ $159.09,145.57,134.38$, and 92.98 in the ${ }^{13} \mathrm{C}-\mathrm{NMR}$ spectrum were assigned to C-4a, C-5a, and C-9a bonded to an oxygen atom, and $\mathrm{C}-11 \mathrm{a}$ bonded to carbonyl carbon, respectively, based on the $\mathrm{HMBC}$ spectrum. c) In the nuclear Overhauser effect (NOE) experiments on 1, an NOE enhancement between the H-6 $(\delta 6.65)$ and H-4 ( $\delta$ 6.26) signals was observed. These results suggested the structure of garcinisidone-A to be $\mathbf{1}$. The results of the NOE experiments on $\mathbf{2}$ (see Experimental) also support

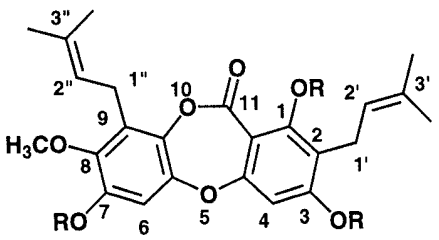

$1 \quad \mathrm{R}=\mathbf{H}$

$2 \mathrm{R}=\mathrm{CH}_{3}$ 


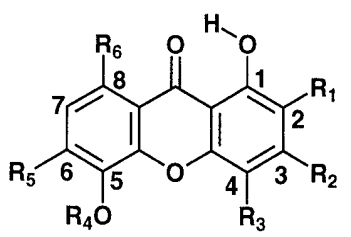

$\begin{array}{llllll}\mathbf{R}_{1} & \mathbf{R}_{2} & \mathbf{R}_{3} & \mathbf{R}_{4} & \mathbf{R}_{5} & \mathbf{R}_{6}\end{array}$

\begin{tabular}{|c|c|c|c|c|c|c|}
\hline & $\mathbf{R}_{1}$ & $\mathbf{R}_{\mathbf{2}}$ & $\mathbf{R}_{3}$ & $\mathbf{R}_{4}$ & $\mathbf{R}_{5}$ & $\mathbf{R}_{6}$ \\
\hline 3 & H & $\mathrm{OH}$ & & H & $\mathrm{OH}$ & $H$ \\
\hline 4 & $\mathrm{H}$ & $\mathrm{OCH}_{3}$ & & H & $\mathrm{OH}$ & H \\
\hline 5 & H & $\mathrm{OCH}_{3}$ & & $\mathrm{CH}_{3}$ & $\mathrm{OCH}_{3}$ & H \\
\hline 6 & $\xi \overbrace{}^{1 "}$ & $\mathrm{OCH}_{3}$ & & H & $\mathrm{OH}$ & $\mathbf{H}$ \\
\hline 7 & H & $\mathrm{OCH}_{3}$ & & H & $\mathrm{OCH}_{3}$ & 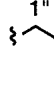 \\
\hline 8 & H & $\mathrm{OH}$ & & $\mathbf{H}$ & $\mathrm{OH}$ & $\mathbf{H}$ \\
\hline 17 & 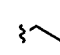 & $\mathrm{OH}$ & $\mathrm{H}$ & $\mathbf{H}$ & $\mathrm{OH}$ & $\mathbf{H}$ \\
\hline 18 & $\mathrm{H}$ & $\mathrm{OH}$ & & H & H & H \\
\hline 19 & $\mathbf{H}$ & $\mathrm{OH}$ & H & H & $H$ & H \\
\hline 20 & H & H & H & H & $\mathbf{H}$ & H \\
\hline
\end{tabular}

the location of the substituents of $\mathbf{1}$. This is the first example of a depsidone derivative having a five-carbon unit (prenyl) to be found in nature.

Structures of Assiguxanthone-A (3), Dulxanthone-A (4), -B (6), and -C (7) Assiguxanthone-A (3), dulxanthone-A (4), -B (6), and -C (7) showed analogous UV absorptions having sharp high-intensity, weak, and broad low-intensity bands at $\lambda_{\max } 252-257,282-285$, and $327-329 \mathrm{~nm}$, respectively. These features were similar to those of ugaxanthone $(\mathbf{8}),{ }^{5)}$ indicating the presence of a $1,3,5,6$ tetraoxygenated xanthone chromophore. We will discuss the structure and location of the substituent in each xanthone below.

Assiguxanthone-A (3) was obtained as a pale yellow powder having the molecular formula $\mathrm{C}_{18} \mathrm{H}_{16} \mathrm{O}_{6}$. The IR spectrum exhibited bands at $v_{\max } 3545,3423,3200$ (br), and $1647 \mathrm{~cm}^{-1}$ due to hydroxyl and carbonyl groups, respectively. In the ${ }^{1} \mathrm{H}-\mathrm{NMR}$ spectrum, a lone $1 \mathrm{H}$ singlet at $\delta 6.29$ and $\mathrm{AB}$-type protons at $\delta 7.56$ and 6.97 (each $1 \mathrm{H}, \mathrm{d}, J=8.4 \mathrm{~Hz}$ ) appeared in addition to a chelated hydroxyl signal at $\delta$ 13.44. The presence of a 1,1- dimethylallyl group at C-4 was indicated by ${ }^{1} \mathrm{H}-\mathrm{NMR}$ signals at $\delta 6.55(1 \mathrm{H}, \mathrm{dd}, J=10.6,17.2 \mathrm{~Hz}), 5.05(1 \mathrm{H}$, br d, $J=17.6 \mathrm{~Hz}), 4.89(1 \mathrm{H}, \mathrm{brd}, J=10.6 \mathrm{~Hz})$, and $1.73(6 \mathrm{H}, \mathrm{s})$, and the cross peaks of $\mathrm{C}-2\left(\delta_{\mathrm{C}} 99.69\right)$ to $1-\mathrm{OH}\left(\delta_{\mathrm{H}} 13.44\right)$ and $\mathrm{C}-4\left(\delta_{\mathrm{C}} 112.69\right)$ to $\mathrm{H}-2\left(\delta_{\mathrm{H}} 6.29\right)$ and to $1^{\prime}-\mathrm{CH}_{3}\left(\delta_{\mathrm{H}}\right.$ $1.73)$ in the $\mathrm{HMBC}$ spectrum. From the aforementioned results and further $\mathrm{HMBC}$ results shown by arrows in Fig. 2, the structure of assiguxanthone-A was concluded to be 3 .

Dulxanthone-A (4) was isolated as a yellow powder, and the molecular formula was determined as $\mathrm{C}_{19} \mathrm{H}_{18} \mathrm{O}_{6}$. The IR spectrum exhibited bands at $v_{\max } 3545$ and $1645 \mathrm{~cm}^{-1}$ due to hydroxyl and carbonyl groups, respectively. The presence of a prenyl moiety in the molecule was indicated by ${ }^{1} \mathrm{H}-\mathrm{NMR}$ signals at $\delta 3.55(2 \mathrm{H}$, $\mathrm{d}, J=7.0 \mathrm{~Hz}), 5.27(1 \mathrm{H}, \mathrm{m}), 1.82(3 \mathrm{H}, \mathrm{s})$, and $1.61(3 \mathrm{H}$, s) and by a fragment ion peak at $m / z 286\left[\mathrm{M}^{+}-\cdot \mathrm{CH}=\right.$ $\left.\mathrm{C}\left(\mathrm{CH}_{3}\right)_{2}-\cdot \mathrm{H}\right]$ in the EI-MS. Further, the ${ }^{1} \mathrm{H}-\mathrm{NMR}$ spectrum revealed an intramolecularly hydrogen-bonded hydroxyl group at $\delta 13.32$, a $1 \mathrm{H}$ singlet at $\delta 6.41$, and two broad $1 \mathrm{H}$ signals at $\delta 7.61$ and 6.97 , and a methoxyl signal 
<smiles>[R6]Oc1c(C)cc2oc3cc(C)c(O[R6])c(P)c3c(=O)c2c1O</smiles>

\begin{tabular}{|c|c|c|c|c|c|}
\hline & $\mathbf{R}_{1}$ & $\mathbf{R}_{2}$ & $\mathbf{R}_{3}$ & $\mathbf{R}_{4}$ & $\mathbf{R}_{5}$ \\
\hline 9 & $T$ & H & $\mathrm{OH}$ & $\mathrm{H}$ & H \\
\hline 10 & & $\mathrm{CH}_{3}$ & $\mathrm{OCH}_{3}$ & $\mathrm{CH}_{3}$ & H \\
\hline 11 & $H$ & $\mathrm{H}$ & $\mathrm{OH}$ & $\mathrm{CH}_{3}$ & \\
\hline 12 & $H$ & $\mathbf{H}$ & $\mathrm{OH}$ & H & \\
\hline 21 & H & H & H & $\mathrm{H}$ & $\mathrm{H}$ \\
\hline 22 & $\xi$ & H & H & H & $\mathbf{H}$ \\
\hline
\end{tabular}

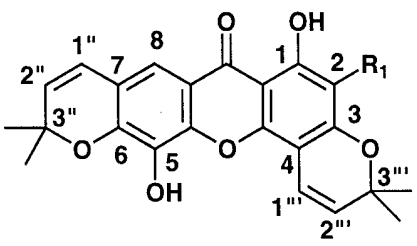<smiles>C=C(C)C(O)C(CC(C)C)C(=O)O</smiles>

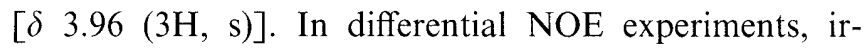
radiation of the methoxy group at $\delta 3.96$ enhanced the signals at $\delta 6.41$. Treatment of this xanthone with diazomethane in $\mathrm{Et}_{2} \mathrm{O}-\mathrm{MeOH}$ gave a dimethyl ether (5), suggesting the presence of two phenolic hydroxyl groups in the original molecule, in addition to an intramolecularly hydrogen-bonded hydroxyl group at $\delta 13.05$. In differential NOE experiments on $\mathbf{5}$, irradiation of the newly formed methoxy group at $\delta 4.01\left(6-\mathrm{OCH}_{3}\right)$ enhanced the signals at $\delta 6.98(\mathrm{H}-7)$. On irradiation of another newly formed methoxy group at $\delta 4.00\left(5-\mathrm{OCH}_{3}\right)$, there was no $\mathrm{NOE}$ enhancement at any proton signal. Irradiation of the original methoxy group at $\delta 3.92\left(3-\mathrm{OCH}_{3}\right)$ enhanced the signal at $\delta 6.38(\mathrm{H}-2)$. In the HMBC spectrum of $\mathbf{5}$, the presence of a significant $\mathrm{C}-\mathrm{H}$ three-bond correlation between a hydrogen-bonded proton at $\delta_{\mathrm{H}} 13.05$ and a carbon at $\delta_{\mathrm{C}} 94.25$ bearing a proton at $\delta_{\mathrm{H}} 6.38(\mathrm{H}-2)$ suggested the location of the prenyl moiety at C-4 (not at $\mathrm{C}-2$ ). Other long-range correlations observed are shown by arrows in Fig. 3. On the basis of these results, the structure of dulxanthone-A is proposed to be 4 .
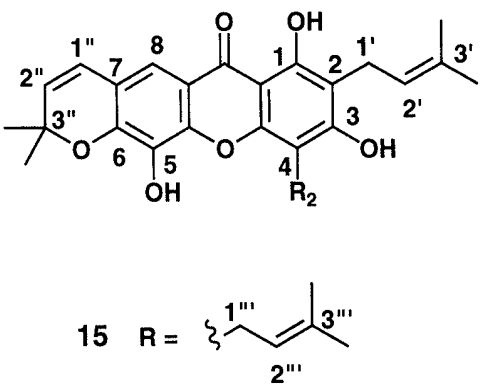

$16 R=H$
Dulxanthone-B (6) was obtained as a yellow oil, $\mathrm{C}_{24} \mathrm{H}_{26} \mathrm{O}_{6}$. The ${ }^{1} \mathrm{H}-\mathrm{NMR}$ spectrum also showed a similar signal pattern to that of $\mathbf{4}$, except for the appearance of signals $[\delta 1.65(3 \mathrm{H}, \mathrm{s}), 1.78(3 \mathrm{H}, \mathrm{s}), 3.37(2 \mathrm{H}, \mathrm{d}, J=6.6 \mathrm{~Hz})$, and $5.33(1 \mathrm{H}, \mathrm{m})$ ] assignable to an additional prenyl side chain $\left[-\mathrm{CH}_{2} \mathrm{CH}=\mathrm{C}\left(\mathrm{CH}_{3}\right)_{2}\right]$, in place of a higher-field sharp $1 \mathrm{H}$ singlet at $\delta 6.41(\mathrm{H}-2)$ in the spectrum of 4 . Mass fragment ions at $m / z 355\left[\mathrm{M}^{+}-\cdot \mathrm{CH}=\mathrm{C}\left(\mathrm{CH}_{3}\right)_{2}\right]$ and 299 $\left[\mathrm{M}^{+}-\cdot \mathrm{CH}=\mathrm{C}\left(\mathrm{CH}_{3}\right)_{2}-\cdot \mathrm{CH}=\mathrm{C}\left(\mathrm{CH}_{3}\right)_{2}-\cdot \mathrm{H}\right]$ in the EI-MS also suggested the presence of two prenyl side chains in the molecule. In the HMBC spectrum, one of the methylene proton signals of the prenyl moieties at $\delta_{\mathrm{H}}$ 3.37 showed long-range correlations with the carbon signals at $\delta_{\mathrm{C}} 159.85(\mathrm{C}-1), 117.44(\mathrm{C}-2)$, and $164.19(\mathrm{C}-3)$. Another signal at $\delta_{\mathrm{H}} 3.61$ was correlated with carbon signals at $\delta_{\mathrm{C}} 153.87(\mathrm{C}-4 \mathrm{a}), 114.44(\mathrm{C}-4)$, and $164.19(\mathrm{C}-3)$. These results suggested the location of the two prenyl moieties at C-2 and C-4, respectively. From these spectral data, we proposed the structure 6 for dulxanthone-B.

Dulxanthone- $\mathrm{C}(7)$ was isolated as a pale yellow powder, $\mathrm{C}_{25} \mathrm{H}_{28} \mathrm{O}_{6}$. The IR spectrum showed absorption bands 
Table 1. ${ }^{1} \mathrm{H}$ - and ${ }^{13} \mathrm{C}-\mathrm{NMR}$ Spectra of a Novel Depsidone

\begin{tabular}{|c|c|c|c|c|}
\hline & \multicolumn{2}{|l|}{1} & \multicolumn{2}{|l|}{2} \\
\hline & $\delta_{\mathrm{H}}$ & $\delta_{\mathrm{C}}$ & $\delta_{\mathrm{H}}$ & $\delta_{\mathrm{c}}$ \\
\hline 1 & & $161.06(\mathrm{~s})$ & & $159.96(\mathrm{~s})$ \\
\hline $1-\mathrm{OH}$ & 9.80 (br) & & & \\
\hline $1-\mathrm{OCH}_{3}$ & & & $3.66(3 \mathrm{H})$ & $62.07(q)$ \\
\hline 2 & & $112.22(\mathrm{~s})$ & & $120.15(\mathrm{~s})$ \\
\hline 3 & & $164.13(\mathrm{~s})$ & & $161.91(\mathrm{~s})$ \\
\hline $3-\mathrm{OCH}_{3}$ & & & $3.88(3 \mathrm{H})$ & $56.44(q)$ \\
\hline 4 & 6.26 & $99.60(d)$ & 6.83 & $98.71(\mathrm{~d})$ \\
\hline $4 a$ & & $159.09(\mathrm{~s})$ & & $161.43(\mathrm{~s})$ \\
\hline $5 \mathrm{a}$ & & $145.57(\mathrm{~s})$ & & $146.95(\mathrm{~s})$ \\
\hline 6 & 6.65 & $105.68(d)$ & 7.02 & $103.45(d)$ \\
\hline 7 & & $148.14(\mathrm{~s})$ & & $149.88(\mathrm{~s})$ \\
\hline $7-\mathrm{OCH}_{3}$ & & & $3.80(3 \mathrm{H})$ & $56.14(q)$ \\
\hline 8 & & $142.94(s)$ & & $143.85(\mathrm{~s})$ \\
\hline $8-\mathrm{OCH}_{3}$ & $3.66(3 \mathrm{H})$ & $60.05(q)$ & $3.69(3 \mathrm{H})$ & $60.55(\mathrm{q})$ \\
\hline 9 & & $127.46(\mathrm{~s})$ & & $127.13(\mathrm{~s})$ \\
\hline $9 \mathrm{a}$ & & $134.38(\mathrm{~s})$ & & $135.11(\mathrm{~s})$ \\
\hline 11 & & $167.17(\mathrm{~s})$ & & $160.88(\mathrm{~s})$ \\
\hline $11 \mathrm{a}$ & & $92.98(\mathrm{~s})$ & & $105.90(\mathrm{~s})$ \\
\hline $1^{\prime}$ & $3.14(2 \mathrm{H}, \mathrm{d}, 7.0)$ & $21.43(\mathrm{t})$ & $3.19(2 \mathrm{H}, \mathrm{d}, 7.0)$ & $22.07(\mathrm{t})$ \\
\hline $2^{\prime}$ & $5.10(\mathrm{~m})$ & $122.31(\mathrm{~d})$ & $5.01(\mathrm{~m})$ & $121.90(\mathrm{~d})$ \\
\hline $3^{\prime}$ & & $130.48(\mathrm{~s})$ & & $131.24(\mathrm{~s})$ \\
\hline \multirow[t]{2}{*}{$3^{\prime}-\mathrm{CH}_{3}$} & $1.67(3 \mathrm{H})$ & $17.66(\mathrm{q})$ & $1.68(3 \mathrm{H})$ & $17.58(q)$ \\
\hline & $1.58(3 \mathrm{H})$ & $25.42(q)$ & $1.56(3 \mathrm{H})$ & $25.27(\mathrm{q})$ \\
\hline $1^{\prime \prime}$ & $3.33(2 \mathrm{H}, \mathrm{d}, 7.0)$ & $23.48(t)$ & $3.34(2 \mathrm{H}, \mathrm{d}, 7.0)$ & $23.24(\mathrm{t})$ \\
\hline $2^{\prime \prime}$ & $5.08(\mathrm{~m})$ & $121.83(\mathrm{~d})$ & $5.01(\mathrm{~m})$ & $121.47(\mathrm{~d})$ \\
\hline $3^{\prime \prime}$ & & $131.64(s)$ & & $132.11(\mathrm{~s})$ \\
\hline \multirow[t]{2}{*}{$3^{\prime \prime}-\mathrm{CH}_{3}$} & $1.74(3 \mathrm{H})$ & $17.76(q)$ & $1.74(3 \mathrm{H})$ & $17.66(q)$ \\
\hline & $1.62(3 \mathrm{H})$ & $25.46(q)$ & $1.59(3 \mathrm{H})$ & $25.37(q)$ \\
\hline
\end{tabular}

Values in $\left(\delta_{\mathrm{H}}, \delta_{\mathrm{C}}\right)$ ppm. ${ }^{1} \mathrm{H}$ - and ${ }^{13} \mathrm{C}$-NMR spectra were recorded at $600 \mathrm{MHz}$ and $150 \mathrm{MHz}$, respectively, in DMSO- $d_{6}$. All signals correspond to $1 \mathrm{H}$, and were observed as a singlet, unless otherwise stated. Figures in parentheses are coupling constants $(J)$ in hertz $(\mathrm{Hz})$.
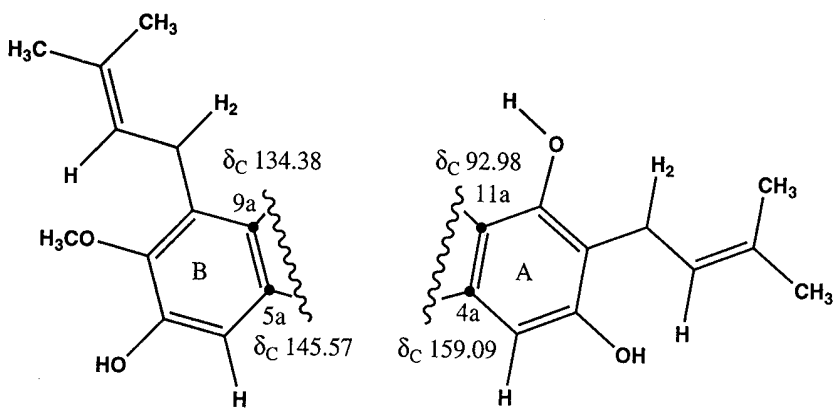

b

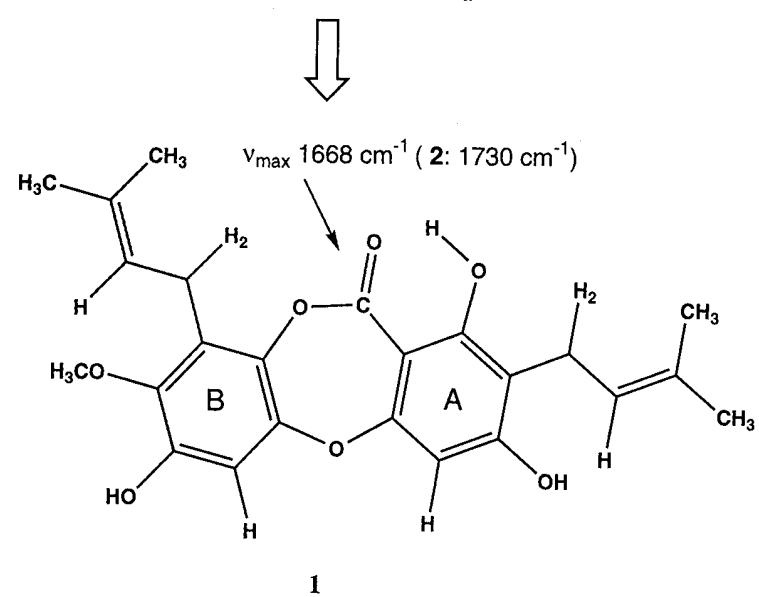

Chart 1. Partial Structures in the Garcinisidone-A (1) Molecule Chemical shift values in the ${ }^{13} \mathrm{C}$-NMR spectrum.

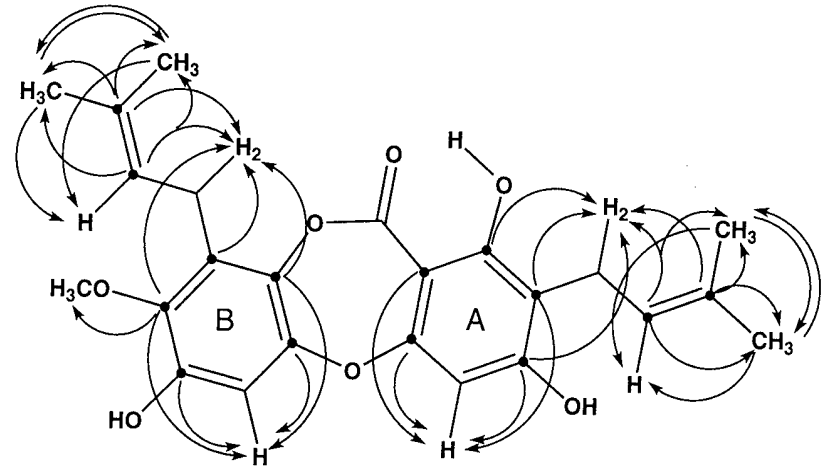

Fig. 1. $\mathrm{C}-\mathrm{H}$ Long-Range Correlations in the HMBC Spectrum of Garcinisidone-A (1) in DMSO- $d_{6}$

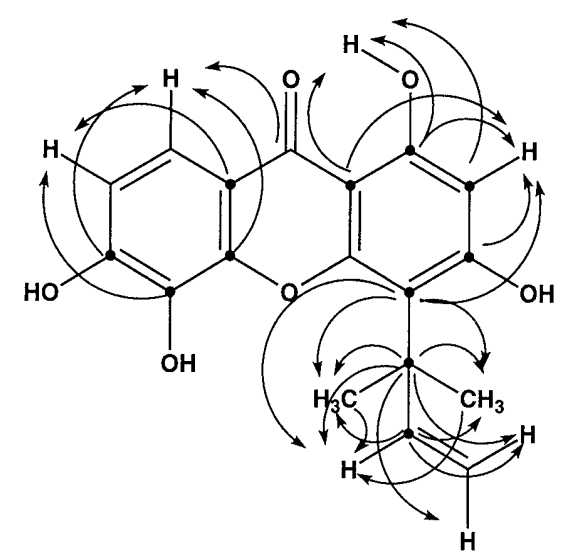

Fig. 2. C-H Long-Range Correlations in the HMBC Spectrum of Assiguxanthone-A (3) in Acetone- $d_{6}$

due to hydroxyl and carbonyl groups at $v_{\max } 3544$ (br) and $1645 \mathrm{~cm}^{-1}$, respectively. In the ${ }^{1} \mathrm{H}-\mathrm{NMR}$ spectrum $\left(\mathrm{CDCl}_{3}\right)$, two $1 \mathrm{H}$ singlets $[\delta 6.33,6.72]$, an $1 \mathrm{H}$ broad signal which disappeared with $\mathrm{D}_{2} \mathrm{O}\left[\begin{array}{ll}\delta & 5.49\end{array}\right]$, and two methoxy signals $[\delta 3.88,3.98]$ appeared in addition to a chelated hydroxyl signal at $\delta 13.42$. The presence of two prenyl moieties in the molecule, as in the case of $\mathbf{6}$, was indicated by ${ }^{1} \mathrm{H}-\mathrm{NMR}$ signals at $\delta 3.50(2 \mathrm{H}, \mathrm{d}, J=7.0 \mathrm{~Hz}$, $\left.\mathrm{H}-1^{\prime}\right), 5.25\left(1 \mathrm{H}, \mathrm{m}, \mathrm{H}-2^{\prime}\right), 1.83\left(3 \mathrm{H}, \mathrm{s}, 3^{\prime}-\mathrm{CH}_{3}\right), 1.74(3 \mathrm{H}$, $\left.\mathrm{s}, 3^{\prime}-\mathrm{CH}_{3}\right)$ and $\delta 4.00\left(2 \mathrm{H}, \mathrm{d}, J=7.0 \mathrm{~Hz}, \mathrm{H}-1^{\prime \prime}\right), 5.34(1 \mathrm{H}$, $\left.\mathrm{m}, \mathrm{H}-2^{\prime \prime}\right), 1.74\left(3 \mathrm{H}, \mathrm{s}, 3^{\prime \prime}-\mathrm{CH}_{3}\right), 1.68\left(3 \mathrm{H}, \mathrm{s}, 3^{\prime \prime}-\mathrm{CH}_{3}\right)$, and by fragment ion peaks at $m / z 369\left[\mathrm{M}^{+}-\cdot \mathrm{CH}=\mathrm{C}\left(\mathrm{CH}_{3}\right)_{2}\right]$ and $313\left[\mathrm{M}^{+}-\cdot \mathrm{CH}=\mathrm{C}\left(\mathrm{CH}_{3}\right)_{2}-\cdot \mathrm{CH}=\mathrm{C}\left(\mathrm{CH}_{3}\right)_{2}-\cdot \cdot \mathrm{H}\right]$ in the EI-MS. The observation of the $\mathrm{H}-1^{\prime \prime}$ proton signal at $\delta 4.00$, which was deshielded by the 9-carbonyl group, indicated the location of one of the prenyls at C-8 on the xanthone nucleus. The location of another prenyl moiety at $\mathrm{C}-4$ was suggested by the presence of a significant $\mathrm{C}-\mathrm{H}$ three-bond correlation between a hydrogen-bonded proton at $\delta_{\mathrm{H}} 13.42$ and a carbon at $\delta_{\mathrm{C}} 94.13$ bearing a proton at $\delta_{\mathrm{H}} 6.33(\mathrm{H}-2)$ in the $\mathrm{HMBC}$ spectrum. In differential NOE experiments, irradiation of the methoxy signal at $\delta 3.88\left(3-\mathrm{OCH}_{3}\right)$ caused an NOE enhancement of the singlet at $\delta 6.33(\mathrm{H}-2)$, and irradiation of another methoxy signal at $\delta 3.98\left(6-\mathrm{OCH}_{3}\right)$ produced an NOE enhancement of the singlet at $\delta 6.72(\mathrm{H}-7)$. Irradiation of the methylene proton signal at $\delta 3.50\left(\mathrm{H}-1^{\prime}\right)$ caused NOE enhancements of the signals at $\delta 5.25\left(\mathrm{H}-2^{\prime}\right)$ and 1.83 $\left(3^{\prime}-\mathrm{CH}_{3}\right)$, respectively. Further, irradiation of another methylene proton signal at $\delta 4.00\left(\mathrm{H}-\mathrm{1}^{\prime \prime}\right)$ resulted in NOE 
Table 2. ${ }^{1} \mathrm{H}-\mathrm{NMR}$ Data for the New Xanthones in Acetone- $d_{6}$

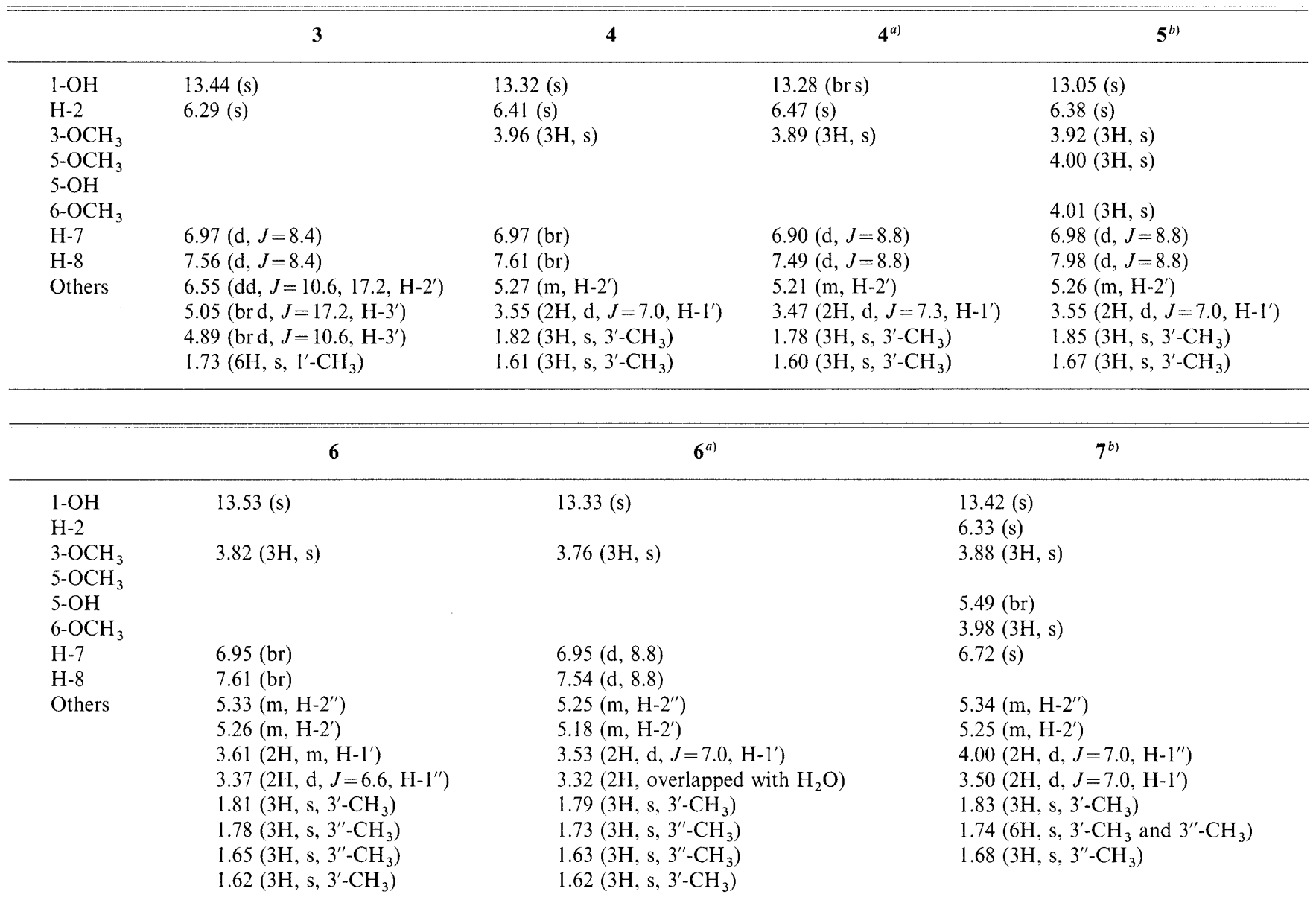

Values in $(\delta) \mathrm{ppm}$. The coupling constants $(J)$ in parentheses are in $\mathrm{Hz}$. All signals correspond to $1 \mathrm{H}$, unless otherwise stated. a) Spectra were taken in DMSO- $d_{6}$. b) Spectra were taken in $\mathrm{CDCl}_{3}$.

Table 3. ${ }^{13} \mathrm{C}-\mathrm{NMR}$ Data for the New Xanthones in Acetone- $d_{6}$

\begin{tabular}{|c|c|c|c|c|c|c|}
\hline & 3 & 4 & $\mathbf{5}^{a)}$ & 6 & $7^{a)}$ & $10^{a)}$ \\
\hline $\mathrm{C}-1$ & $162.12(\mathrm{~s})$ & $163.05(\mathrm{~s})$ & $162.02(\mathrm{~s})$ & $159.85(\mathrm{~s})$ & $162.25(\mathrm{~s})$ & $159.31(\mathrm{~s})$ \\
\hline $\mathrm{C}-2$ & 99.69 (d) & 94.77 (d) & $94.25(\mathrm{~d})$ & $117.44(\mathrm{~s})$ & 94.13 (d) & $111.78(\mathrm{~s})$ \\
\hline C-3 & $164.50(\mathrm{~s})$ & $164.82(\mathrm{~s})$ & $164.12(\mathrm{~s})$ & $164.19(\mathrm{~s})$ & $163.47(\mathrm{~s})$ & $163.73(\mathrm{~s})$ \\
\hline $3-\mathrm{OCH}_{3}$ & & $56.58(q)$ & $56.03(q)$ & $62.14(\mathrm{q})$ & $55.97(q)$ & $55.87(q)$ \\
\hline C- -4 & $112.69(\mathrm{~s})$ & $108.55(\mathrm{~s})$ & $108.17(\mathrm{~s})$ & $114.44(\mathrm{~s})$ & $106.99(\mathrm{~s})$ & 89.42 (d) \\
\hline$C-4 a$ & $156.83(\mathrm{~s})$ & $154.76(\mathrm{~s})$ & $153.99(\mathrm{~s})$ & $153.87(\mathrm{~s})$ & $153.22(\mathrm{~s})$ & $156.14(\mathrm{~s})$ \\
\hline$C-6$ & $151.77(\mathrm{~s})$ & $153.23(\mathrm{~s})$ & $157.85(\mathrm{~s})$ & $153.40(\mathrm{~s})$ & $150.12(\mathrm{~s})$ & $155.36(\mathrm{~s})$ \\
\hline $\mathrm{C}-7$ & $113.64(\mathrm{~d})$ & $113.57(\mathrm{~d})$ & $108.33(d)$ & $114.09(\mathrm{~d})$ & $108.79(\mathrm{~d})$ & $146.64(\mathrm{~s})$ \\
\hline C-8 & $116.96(d)$ & $117.32(\mathrm{~d})$ & $121.50(\mathrm{~d})$ & $117.44(d)$ & $136.44(s)$ & $104.64(\mathrm{~s})$ \\
\hline C-8a & $114.34(\mathrm{~s})$ & $114.37(\mathrm{~s})$ & $115.16(\mathrm{~s})$ & $113.96(\mathrm{~s})$ & $112.42(\mathrm{~s})$ & $113.51(\mathrm{~s})$ \\
\hline C-9 & $181.52(\mathrm{~s})$ & $181.67(\mathrm{~s})$ & $180.82(\mathrm{~s})$ & $182.23(\mathrm{~s})$ & $182.92(\mathrm{~s})$ & $179.79(\mathrm{~s})$ \\
\hline C-9a & $103.42(\mathrm{~s})$ & $103.23(\mathrm{~s})$ & $102.92(\mathrm{~s})$ & $105.90(\mathrm{~s})$ & $103.57(\mathrm{~s})$ & $103.47(d)$ \\
\hline $\mathrm{C}-10 \mathrm{a}$ & $146.78(\mathrm{~s})$ & $147.42(s)$ & $150.63(\mathrm{~s})$ & $147.56(\mathrm{~s})$ & $145.84(\mathrm{~s})$ & $152.24(\mathrm{~s})$ \\
\hline \multirow{9}{*}{ Other } & $107.89\left(t, C-3^{\prime}\right)$ & $131.73\left(\mathrm{~s}, \mathrm{C}-3^{\prime}\right)$ & $132.02\left(\mathrm{~s}, \mathrm{C}-3^{\prime}\right)$ & $124.10\left(\mathrm{~d}, \mathrm{C}-2^{\prime}\right.$ or $\left.\mathrm{C}-2^{\prime \prime}\right)$ & $122.73\left(\mathrm{~d}, \mathrm{C}-2^{\prime}\right)$ & $131.89\left(\mathrm{~s}, \mathrm{C}-3^{\prime}\right)$ \\
\hline & $29.93\left(\mathrm{q} \times 2,1^{\prime}-\mathrm{CH}_{3}\right.$, & $25.93\left(\mathrm{q}, 3^{\prime}-\mathrm{CH}_{3}\right)$ & $25.80\left(\mathrm{q}, 3^{\prime}-\mathrm{CH}_{3}\right)$ & $123.80\left(\mathrm{~d}, \mathrm{C}-2^{\prime \prime}\right.$ or $\left.\mathrm{C}-2^{\prime}\right)$ & $122.90\left(\mathrm{~d}, \mathrm{C}-2^{\prime \prime}\right)$ & $25.81\left(\mathrm{q}, 3^{\prime}-\mathrm{CH}_{3}\right)$ \\
\hline & overlapped with acetone) & $17.94\left(\mathrm{q}, 3^{\prime}-\mathrm{CH}_{3}\right)$ & $17.77\left(\mathrm{q}, 3^{\prime}-\mathrm{CH}_{3}\right)$ & $131.78\left(\mathrm{~s}, \mathrm{C}-3^{\prime}\right.$ or $\left.\mathrm{C}-3^{\prime \prime}\right)$ & $132.94\left(\mathrm{~s}, \mathrm{C}-3^{\prime \prime}\right)$ & $17.80\left(\mathrm{q}, 3^{\prime}-\mathrm{CH}_{3}\right)$ \\
\hline & & & $61.31\left(\mathrm{q}, 5-\mathrm{OCH}_{3}\right)$ & $131.68\left(\mathrm{~s}, \mathrm{C}-3^{\prime \prime}\right.$ or $\left.\mathrm{C}-3^{\prime}\right)$ & $131.50\left(\mathrm{~s}, \mathrm{C}-3^{\prime}\right)$ & $56.46\left(\mathrm{q}, 6-\mathrm{OCH}_{3}\right)$ \\
\hline & & & $56.43\left(\mathrm{q}, 6-\mathrm{OCH}_{3}\right)$ & $25.87\left(\mathrm{q}, 3^{\prime}-\mathrm{CH}_{3}\right.$ or $\left.3^{\prime \prime} \mathrm{CH}_{3}\right)$ & $25.86\left(\mathrm{q}, 3^{\prime \prime}-\mathrm{CH}_{3}\right)$ & $56.36\left(\mathrm{q}, 7-\mathrm{OCH}_{3}\right)$ \\
\hline & & & & $25.80\left(\mathrm{q}, 3^{\prime \prime}-\mathrm{CH}_{3}\right.$ or $\left.3^{\prime}-\mathrm{CH}_{3}\right)$ & $25.73\left(\mathrm{q}, 3^{\prime}-\mathrm{CH}_{3}\right)$ & \\
\hline & & & & $18.05\left(\mathrm{q}, 3^{\prime}-\mathrm{CH}_{3}\right.$ or $\left.3^{\prime \prime}-\mathrm{CH}_{3}\right)$ & $18.07\left(\mathrm{q}, 3^{\prime \prime}-\mathrm{CH}_{3}\right)$ & \\
\hline & & & & $17.95\left(\mathrm{q}, 3^{\prime \prime}-\mathrm{CH}_{3}\right.$ or $\left.3^{\prime}-\mathrm{CH}_{3}\right)$ & $17.77\left(q, 3^{\prime}-\mathrm{CH}_{3}\right)$ & \\
\hline & & & & & $56.30\left(\mathrm{q}, 7-\mathrm{OCH}_{3}\right)$ & \\
\hline
\end{tabular}

Values in $(\delta)$ ppm. a) Spectrum were taken in $\mathrm{CDCl}_{3}$. 
enhancements of the signals at $\delta 6.72(\mathrm{H}-7), 5.34\left(\mathrm{H}-2^{\prime \prime}\right)$, and $1.74\left(3^{\prime \prime}-\mathrm{CH}_{3}\right)$. Based on these spectral data, coupled with the results of $\mathrm{HMBC}$ experiments, shown by arrows in Fig. 4, the structure of dulxanthone-C was concluded to be 7 .

Structure of Assiguxanthone-B (9) and Dulxanthone-D (11) The close similarity of the UV spectra of the two new xanthones [assiguxanthone-B (9) and dulxanthone-D (11)] and 1,3,6,7-tetrahydroxy-8-(3-methylbut-2-enyl)xanthone $(\mathbf{1 2}),{ }^{6}$ which was isolated from the same plant, suggested that these xanthone (9) and (11) may have the same basic skeleton, a 1,3,6,7-tetraoxygenated xanthone.

Assiguxanthone-B (9) was isolated as a pale yellow powder, $\mathrm{C}_{18} \mathrm{H}_{16} \mathrm{O}_{6}$. The ${ }^{1} \mathrm{H}-\mathrm{NMR}$ spectrum showed three $1 \mathrm{H}$ singlets $\left[\delta_{\mathrm{H}} 7.52,6.87,6.43\right]$ in addition to a chelated hydroxyl signal at $\delta 13.52(1-\mathrm{OH})$. One $(\delta 7.52)$ of them was assignable to $\mathrm{H}-8$, which was deshielded by the 9-carbonyl group. The presence of a prenyl moiety in the molecule was indicated by ${ }^{1} \mathrm{H}-\mathrm{NMR}$ signals $[\delta 3.34(2 \mathrm{H}$, $\mathrm{d}, J=7.3 \mathrm{~Hz}), 5.27(1 \mathrm{H}, \mathrm{m}), 1.77(3 \mathrm{H}, \mathrm{s})$, and $1.63(3 \mathrm{H}$, s)] and by a base fragment ion peak at $m / z 273\left[\mathrm{M}^{+} \ldots\right.$. $\left.\mathrm{CH}=\mathrm{C}\left(\mathrm{CH}_{3}\right)_{2}\right]$ in the EI-MS. Further confirmation of the structure was performed by treatment of 9 with diazomethane in a usual manner to give a trimethylated derivative (10). The ${ }^{1} \mathrm{H}-\mathrm{NMR}$ spectrum of $\mathbf{1 0}$ showed a similar signal pattern to that of 9 , except for three $3 \mathrm{H}$ singlets at $\delta_{\mathrm{H}} 4.01,3.99$, and 3.92 due to three methoxy

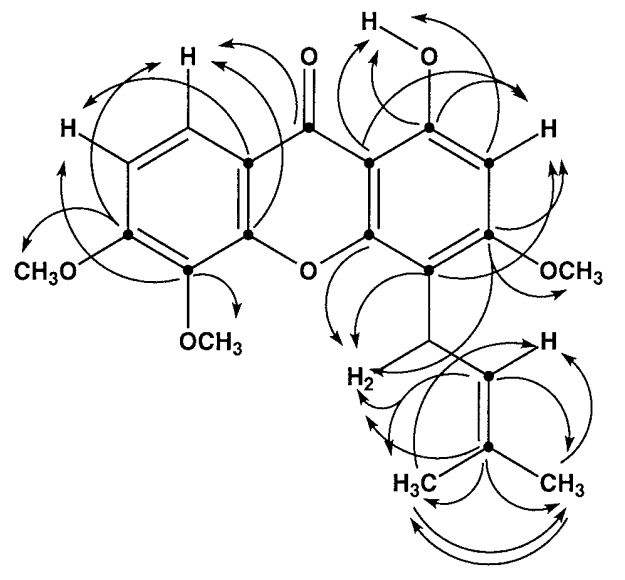

Fig. 3. $\mathrm{C}-\mathrm{H}$ Long-Range Correlations in the $\mathrm{HMBC}$ Spectrum of Dulxanthone-A Dimethyl Ether (5) in $\mathrm{CDCl}_{3}$ groups. The location of a prenyl moiety at C-2 (not at $\mathrm{C}-4$ ) was indicated by a significant $\mathrm{C}-\mathrm{H}$ three- or two-bond correlation between a hydrogen-bonded proton at $\delta_{\mathrm{H}} 13.05$ and a carbon at $\delta_{\mathrm{C}} 111.78(\mathrm{C}-2)$, which was also related to the methylene protons $\left(\mathrm{H}-1^{\prime}, \delta_{\mathrm{H}} 3.38\right)$ on the prenyl moiety, in the HMBC spectrum of $\mathbf{1 0}$. Other $\mathrm{C}-\mathrm{H}$ longrange correlations observed are shown by arrows in Fig. 5. Based on these results, we assigned structure 9 to assiguxanthone-B.

Dulxanthone-D (11) was obtained as a yellow powder, $\mathrm{C}_{19} \mathrm{H}_{18} \mathrm{O}_{6}$, and IR bands appeared at $v_{\max } 3400(\mathrm{br})$ and $1647 \mathrm{~cm}^{-1}$ (hydroxyl and carbonyl groups, respectively). In the ${ }^{1} \mathrm{H}-\mathrm{NMR}$ spectrum, a lone $1 \mathrm{H}$ singlet at $\delta 6.85$, meta-coupled doublets at $\delta 6.28(\mathrm{H}-2)$ and $6.22(\mathrm{H}-4)$ (each $1 \mathrm{H}, J=2.2 \mathrm{~Hz}$ ), and a methoxy signal at $\delta 3.81$ appeared, in addition to a chelated hydroxyl signal at $\delta 13.43(1-\mathrm{OH})$. Further, two $3 \mathrm{H}$ singlets $(\delta 1.83,1.70)$, a $2 \mathrm{H}$ doublet $(\delta$ $4.08, J=6.2 \mathrm{~Hz})$, and a $1 \mathrm{H}$ multiplet $(\delta 5.27)$ in the ${ }^{1} \mathrm{H}-\mathrm{NMR}$ spectrum, and a fragment ion peak at $\mathrm{m} / \mathrm{z} 285$ $\left[\mathrm{M}^{+}-\cdot \mathrm{CH}=\mathrm{C}\left(\mathrm{CH}_{3}\right)_{2}-\cdot \mathrm{H}\right]$ in the EI-MS indicated the presence of a prenyl moiety in the molecule. The appearance of the deshielded methylene signal at $\delta 4.08$

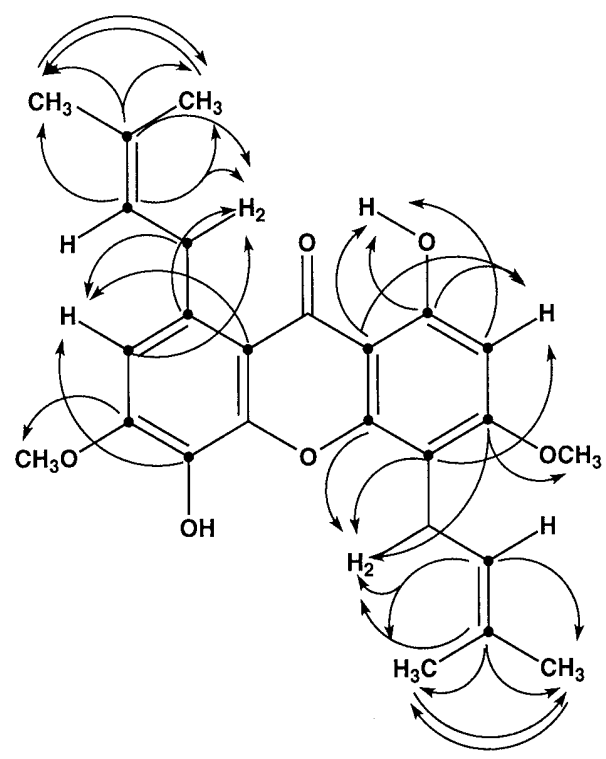

Fig. 4. $\mathrm{C}-\mathrm{H}$ Long-Range Correlations in the $\mathrm{HMBC}$ Spectrum of Dulxanthone-C (7) in $\mathrm{CDCl}_{3}$

Table 4. ${ }^{1} \mathrm{H}-\mathrm{NMR}$ Data for the New Xanthones in $\mathrm{CDCl}_{3}$

\begin{tabular}{|c|c|c|c|}
\hline & $9^{a)}$ & 10 & 11 \\
\hline $1-\mathrm{OH}$ & $13.52(\mathrm{~s})$ & $13.05(\mathrm{~s})$ & $13.43(\mathrm{~s})$ \\
\hline $\mathrm{H}-2$ & & & $6.28(\mathrm{~d}, J=2.2)$ \\
\hline $3-\mathrm{OCH}_{3}$ & & $3.92(3 \mathrm{H}, \mathrm{s})$ & \\
\hline $\mathrm{H}-4$ & $6.43(\mathrm{~s})$ & $6.41(\mathrm{~s})$ & $6.22(\mathrm{~d}, J=2.2)$ \\
\hline $\mathrm{H}-5$ & $6.87(\mathrm{~s})$ & $6.86(\mathrm{~s})$ & $6.85(\mathrm{~s})$ \\
\hline $6-\mathrm{OCH}_{3}$ & & $4.01(3 \mathrm{H}, \mathrm{s})$ & \\
\hline $7-\mathrm{OCH}_{3}$ & & $3.99(3 \mathrm{H}, \mathrm{s})$ & \\
\hline $\mathrm{H}-8$ & $7.52(\mathrm{~s})$ & $7.58(\mathrm{~s})$ & \\
\hline \multirow{5}{*}{ Others } & $5.27\left(\mathrm{~m}, \mathrm{H}-2^{\prime}\right)$ & $5.24\left(\mathrm{~m}, \mathrm{H}-2^{\prime}\right)$ & $5.27\left(\mathrm{~m}, \mathrm{H}-2^{\prime}\right)$ \\
\hline & $3.34\left(2 \mathrm{H}, \mathrm{d}, J=7.3, \mathrm{H}-\mathrm{l}^{\prime}\right)$ & $3.38\left(2 \mathrm{H}, \mathrm{d}, J=7.0, \mathrm{H}-\mathrm{I}^{\prime}\right)$ & $4.08\left(2 \mathrm{H}, \mathrm{d}, J=6.2, \mathrm{H}^{-1} \mathrm{l}^{\prime}\right)$ \\
\hline & $1.77\left(3 \mathrm{H}, \mathrm{s}, 3^{\prime}-\mathrm{CH}_{3}\right)$ & $1.81\left(3 \mathrm{H}, \mathrm{s}, 3^{\prime}-\mathrm{CH}_{3}\right)$ & $3.81\left(3 \mathrm{H}, \mathrm{s}, 7-\mathrm{OCH}_{3}\right)$ \\
\hline & $1.63\left(3 \mathrm{H}, \mathrm{s}, 3^{\prime}-\mathrm{CH}_{3}\right)$ & $1.69\left(3 \mathrm{H}, \mathrm{s}, 3^{\prime}-\mathrm{CH}_{3}\right)$ & $1.83\left(3 \mathrm{H}, \mathrm{s}, 3^{\prime}-\mathrm{CH}_{3}\right)$ \\
\hline & & & $1.70\left(3 \mathrm{H}, \mathrm{s}, 3^{\prime}-\mathrm{CH}_{3}\right)$ \\
\hline
\end{tabular}




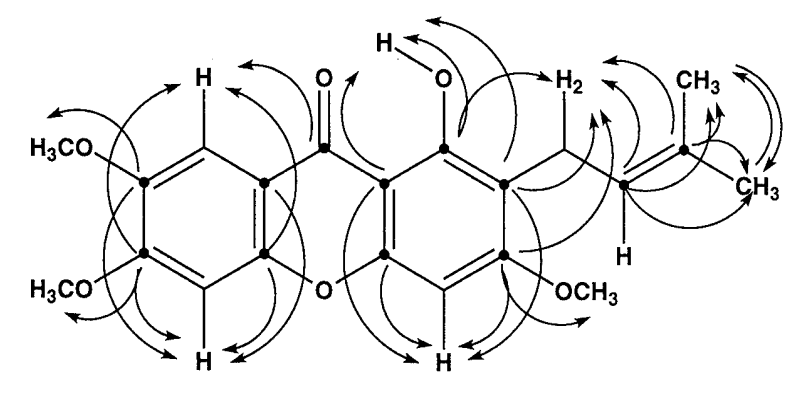

Fig. 5. C-H Long-Range Correlations in the HMBC Spectrum of Assiguxanthone-B Methyl Ether (10) in $\mathrm{CDCl}_{3}$

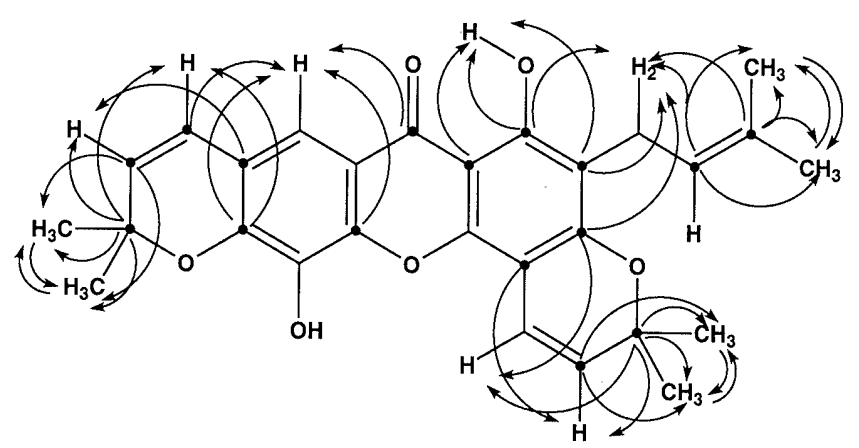

Fig. 6. $\mathrm{C}-\mathrm{H}$ Long-Range Correlations in the HMBC Spectrum of Latisxanthone- $\mathrm{A}(\mathbf{1 3})$ in $\mathrm{CDCl}_{3}$

$\left(\mathrm{H}-1^{\prime}\right)$ indicated the presence of the prenyl moiety at $\mathrm{C}-8$ on the xanthone nucleus. In differential NOE experiments, irradiation of the methoxy signal at $\delta 3.81\left(7-\mathrm{OCH}_{3}\right)$ caused a $3 \%$ NOE enhancement of the signal at $\delta 4.08$ $\left(\mathrm{H}-1^{\prime}\right)$. From the above results, the structure of dulxanthone-D was concluded to be $\mathbf{1 1}$, corresponding to the methylated derivative of a known compound (12). ${ }^{5)}$

Structure of Latisxanthone-A (13) Latisxanthone-A (13) was obtained as a yellow powder. The molecular formula was determined to be $\mathrm{C}_{28} \mathrm{H}_{28} \mathrm{O}_{6}$ by HR-MS. The UV (see Experimental) and IR bands at $v_{\max } 3539$ (br, $\mathrm{OH})$ and $1635(\mathrm{C}=\mathrm{O}) \mathrm{cm}^{-1}$ suggested the presence of a 1,3,5,6-tetraoxygenated xanthone chromophore in the molecule. ${ }^{7)}$ In the ${ }^{1} \mathrm{H}-\mathrm{NMR}$ spectrum, a lone $1 \mathrm{H}$ singlet at $\delta 7.47$, which was assignable to $\mathrm{H}-8$, and a $\mathrm{D}_{2} \mathrm{O}-$ exchangeable broad signal at $\delta 5.46(5-\mathrm{OH})$ appeared in addition to a chelated hydroxyl signal at $\delta 13.28$ (1-OH). Two pairs of doublets at $\delta 5.70,6.42($ each $1 \mathrm{H}, J=9.9 \mathrm{~Hz}$ ) and $\delta 5.58,6.88$ (each $1 \mathrm{H}, J=9.9 \mathrm{~Hz}$ ), together with two $6 \mathrm{H}$-singlets at $\delta 1.51$ and 1.46 , indicated the presence of two dimethylpyran ring systems in the molecule. Further, the presence of a prenyl moiety was indicated by two $3 \mathrm{H}$ singlets $(\delta 1.80,1.67)$, a $2 \mathrm{H}$ doublet $(\delta 3.33, J=7.2 \mathrm{~Hz})$, and a $1 \mathrm{H}$ multiplet $\left(\delta\right.$ 5.24) in the ${ }^{1} \mathrm{H}-\mathrm{NMR}$ spectrum, and a fragment ion peak at $m / z$ 405 $\left[\mathrm{M}^{+}-\cdot \mathrm{CH}=\right.$ $\left.\mathrm{C}\left(\mathrm{CH}_{3}\right)_{2}\right]$ in EI-MS. In an NOE experiment, irradiation of the H-8 signal at $\delta 7.47$ caused an enhancement of the $\mathrm{H}-1^{\prime \prime}$ signal $(\delta 6.42)$ indicating the presence of a dimethylpyran ring fused with the 1,3,5,6-tetraoxygenated xanthone nucleus at C-6 and C-7. The structure of $\mathbf{1 3}$ was confirmed by HMQC and HMBC experiments as follows. The presence of a prenyl moiety at C-2 was suggested by a significant $\mathrm{C}-\mathrm{H}$ three- or two-bond correlation between a hydrogen-bonded proton at $\delta_{\mathrm{H}} 13.28$ and a carbon at $\delta_{\mathrm{C}} 111.69(\mathrm{C}-2)$, which was also related to the methylene protons $\left(\mathrm{H}-1^{\prime}, \delta_{\mathrm{H}} 3.33\right)$ on the prenyl moiety, respectively, in the HMBC spectrum. The presence of a dimethylpyran ring fused with the 1,3,5,6-tetraoxygenated xanthone nucleus at C-6 and C-7 was also suggested by a $\mathrm{C}-\mathrm{H}$ three-bond correlation between a lone deshielded $1 \mathrm{H}$ singlet $\left(\mathrm{H}-8, \delta_{\mathrm{H}} 7.47\right)$ and a carbon at $\delta_{\mathrm{C}} 121.48\left(\mathrm{C}-1^{\prime \prime}\right)$ bearing a proton at $\delta_{\mathrm{H}} 6.42\left(\mathrm{H}-1^{\prime \prime}\right)$. Further, the observation of a $\mathrm{C}-\mathrm{H}$ three-bond correlation between a $1 \mathrm{H}$ doublet proton $\left(\mathrm{H}-\mathrm{I}^{\prime \prime \prime}, \delta_{\mathrm{H}} 6.88\right)$ and a carbon at $\delta_{\mathrm{C}} 158.14$ (C-3), which was also related to the methylene protons $\left(\mathrm{H}-1^{\prime}, \delta_{\mathrm{H}} 3.33\right)$, indicated the presence of another dimethylpyran ring fused with the 1,3,5,6-tetraoxygenated xanthone nucleus at C-3 and C-4. Other C-H long-range correlations observed are shown by arrows in Fig. 6. On the basis of these results, the structure of latisxanthone-A is proposed to be $\mathbf{1 3 .}$

Structure of Latisxanthone-B (14) Latisxanthone-B (14), $[\alpha]_{\mathrm{D}}+5^{\circ}\left(\mathrm{CHCl}_{3}\right)$, was obtained as a yellow powder. The molecular formula $\mathrm{C}_{28} \mathrm{H}_{28} \mathrm{O}_{8}$, a difference of $\mathrm{O}_{2}$ compared with 13, was established by HR-FAB-MS. The UV spectrum (see Experimental) was similar to that of 13. The ${ }^{1} \mathrm{H}-\mathrm{NMR}$ spectrum also showed a similar signal pattern to that of $\mathbf{1 3}$, except for the following signals in place of the signals due to a prenyl side chain $\left[-\mathrm{CH}_{2} \mathrm{CH}=\right.$ $\left.\mathrm{C}\left(\mathrm{CH}_{3}\right)_{2}\right]$. ABC-type signals at $\delta 2.96(1 \mathrm{H}, \mathrm{dd}, J=4.4$, $13.9 \mathrm{~Hz}), 3.09(1 \mathrm{H}, \mathrm{dd}, J=8.8,13.9 \mathrm{~Hz})$, and $4.39(1 \mathrm{H}, \mathrm{dd}$, $J=4.4,8.8 \mathrm{~Hz}$ ), two $1 \mathrm{H}$ broad singlets at $\delta 4.94$ and 4.95 assignable to exo-methylene protons, and a $3 \mathrm{H}$ singlet at $\delta 1.85$ due to a vinyl methyl group were observed, as well as the broad singlet at $\delta 9.07$ which disappeared on addition of $\mathrm{D}_{2} \mathrm{O}$. Signals at $\delta_{\mathrm{H}} 4.39$, one of the ABC-type protons, and $\delta_{\mathrm{C}} 86.52(\mathrm{~d})$ in the ${ }^{1} \mathrm{H}$ - and ${ }^{13} \mathrm{C}$-NMR spectra, respectively, together with a fragment ion peak at $m / z 476$ corresponding to $\left[\mathrm{M}^{+}-\cdot \mathrm{O}\right]$ in the EI-MS, suggested the presence of a hydroperoxy moiety in this xanthone. These data, coupled with two significant mass fragment ion peaks at $m / z \quad 405(100 \%)$ and $391(16 \%)$ ascribed to ions $\left[\mathrm{M}^{+}-\cdot \mathrm{CH}(\mathrm{OOH})-\mathrm{C}\left(\mathrm{CH}_{3}\right)=\mathrm{CH}_{2}\right]$ and $\left[\mathrm{M}^{+}-\cdot \mathrm{CH}_{2}^{--}\right.$ $\left.\mathrm{CH}(\mathrm{OOH})-\mathrm{C}\left(\mathrm{CH}_{3}\right)=\mathrm{CH}_{2}\right]$, respectively, indicated the structure $\left[-\mathrm{CH}_{2}-\mathrm{CH}(\mathrm{OOH})-\mathrm{C}\left(\mathrm{CH}_{3}\right)=\mathrm{CH}_{2}\right]$ for the side chain. These results suggested the structure of latisxanthone-B to be 14. The structure 14 was further confirmed by HMQC and HMBC experiments as shown by arrows in Fig. 7.

This is the second example of the isolation of a hydroperoxygenated xanthone from a natural source. ${ }^{8)}$

Structure of Latisxanthone-C (15) Latisxanthone-C (15) was obtained as a pale yellow powder, $\mathrm{C}_{28} \mathrm{H}_{30} \mathrm{O}_{6}$. The UV absorptions (see Experimental), and IR bands at $v_{\max } 3543,3377$ (br) and $1637 \mathrm{~cm}^{-1}$ due to hydroxyl and carbonyl groups, respectively, suggested the presence of a 1,3,5,6-tetraoxygenated xanthone chromophore in the molecule. ${ }^{7)}$ In the ${ }^{1} \mathrm{H}-\mathrm{NMR}$ spectrum, a lone deshielded $1 \mathrm{H}$ singlet $[\delta 7.48]$, two broad signals which disappeared with $\mathrm{D}_{2} \mathrm{O}[\delta 5.48,6.43]$, and two set of signals due to prenyl moieties $[\delta 3.46(2 \mathrm{H}, \mathrm{d}, J=7.3 \mathrm{~Hz}), 5.29(1 \mathrm{H}, \mathrm{m})$, $1.85(3 \mathrm{H}, \mathrm{s}), 1.77(3 \mathrm{H}, \mathrm{s})$ and $\delta 3.60(2 \mathrm{H}, \mathrm{d}, J=7.0 \mathrm{~Hz})$, $5.32(1 \mathrm{H}, \mathrm{m}), 1.89(3 \mathrm{H}, \mathrm{s}), 1.75(3 \mathrm{H}, \mathrm{s})]$ appeared in addition to a chelated hydroxyl signal at $\delta 13.31$. Further, the ${ }^{1} \mathrm{H}-\mathrm{NMR}$ spectrum showed a singlet $(6 \mathrm{H})$ at $\delta 1.53$ assignable to geminal dimethyls attached to an oxygenated 
Table 5. ${ }^{1} \mathrm{H}-\mathrm{NMR}$ Data for the New Pyranoxanthones in $\mathrm{CDCl}_{3}$

\begin{tabular}{|c|c|c|c|c|}
\hline & 13 & 14 & 15 & 16 \\
\hline $\begin{array}{l}1-\mathrm{OH} \\
\mathrm{H}-4\end{array}$ & $13.28(\mathrm{~s})$ & $13.81(\mathrm{~s})$ & $13.31(\mathrm{~s})$ & $13.32(\mathrm{~s})$ \\
\hline $\begin{array}{l}\mathrm{H}-4 \\
5-\mathrm{OH}\end{array}$ & $5.46(\mathrm{br})$ & $5.42(\mathrm{br})$ & $5.48(\mathrm{br})$ & $6.42(\mathrm{~s})$ \\
\hline $\mathrm{H}-8$ & $7.47(\mathrm{~s})$ & $7.42(\mathrm{~s})$ & $7.48(\mathrm{~s})$ & $7.43(\mathrm{~s})$ \\
\hline $\begin{array}{l}\mathrm{H}-\mathrm{\gamma} \\
\mathrm{H}-\mathrm{I}^{\prime}\end{array}$ & $3.33(2 \mathrm{H}, \mathrm{d}, J=7.3)$ & $\begin{array}{l}2.96(\mathrm{dd}, J=4.4,13.9) \\
3.09(\mathrm{dd}, J=8.8,13.9)\end{array}$ & $3.46(2 \mathrm{H}, \mathrm{d}, J=7.3)$ & $3.40(2 \mathrm{H}, \mathrm{d}, J=7.0)$ \\
\hline $\begin{array}{l}\mathrm{H}-2^{\prime} \\
3^{\prime}-\mathrm{CH}_{2}\end{array}$ & $5.24(\mathrm{~m})$ & $\begin{array}{l}4.39(\mathrm{dd}, J=4.4,8.8) \\
4.94(\mathrm{br} \mathrm{s}) \\
4.95(\mathrm{brs})\end{array}$ & $5.29^{a)}(\mathrm{m})$ & $5.24(\mathrm{~m})$ \\
\hline $3^{\prime}-\mathrm{CH}_{3}$ & $\begin{array}{l}1.80(3 \mathrm{H}, \mathrm{s}) \\
1.67(3 \mathrm{H}, \mathrm{s})\end{array}$ & $1.85(3 \mathrm{H}, \mathrm{s})$ & $\begin{array}{l}1.85^{a)}(3 \mathrm{H}, \mathrm{s}) \\
1.77^{a)}(3 \mathrm{H}, \mathrm{s})\end{array}$ & $\begin{array}{l}1.78(3 \mathrm{H}, \mathrm{s}) \\
1.71(3 \mathrm{H}, \mathrm{s})\end{array}$ \\
\hline $\begin{array}{l}\mathrm{H}-1^{\prime \prime} \\
\mathrm{H}-2^{\prime \prime} \\
3^{\prime \prime}-\mathrm{CH}_{3} \\
\text { Others }\end{array}$ & $\begin{array}{l}6.42(\mathrm{~d}, J=9.9) \\
5.70(\mathrm{~d}, J=9.9) \\
1.51(6 \mathrm{H}, \mathrm{s}) \\
6.88\left(\mathrm{~d}, J=9.9, \mathrm{H}-1^{\prime \prime \prime}\right) \\
5.58\left(\mathrm{~d}, J=9.9, \mathrm{H}^{\prime \prime \prime}\right) \\
1.46\left(6 \mathrm{H}, \mathrm{s}, 3^{\prime \prime \prime}-\mathrm{CH}_{3}\right)\end{array}$ & $\begin{array}{l}6.38(\mathrm{~d}, J=9.9) \\
5.67(\mathrm{~d}, J=9.9) \\
1.45(6 \mathrm{H}, \mathrm{s}) \\
9.07(\mathrm{brs}, \mathrm{OOH}) \\
6.85\left(\mathrm{~d}, J=9.9,{\left.\mathrm{H}-1^{\prime \prime \prime}\right)}^{\prime \prime}\right. \\
5.55\left(\mathrm{~d}, J=9.9,{\left.\mathrm{H}-2^{\prime \prime \prime}\right)} .42\left(6 \mathrm{H}, \mathrm{s}, 3^{\prime \prime \prime}-\mathrm{CH}_{3}\right)\right.\end{array}$ & $\begin{array}{l}6.44(\mathrm{~d}, J=9.9) \\
5.72(\mathrm{~d}, J=9.9) \\
1.53(6 \mathrm{H}, \mathrm{s}) \\
6.43(\mathrm{~s}, 3-\mathrm{OH}) \\
3.60\left(2 \mathrm{H}, \mathrm{d}, J=7.0, \mathrm{H}-1^{\prime \prime \prime}\right) \\
5.32^{a)}\left(\mathrm{m}, \mathrm{H}-2^{\prime \prime \prime}\right) \\
1.89^{a)}\left(3 \mathrm{H}, \mathrm{s}, 3^{\prime \prime \prime}-\mathrm{CH}_{3}\right) \\
1.75^{a)}\left(3 \mathrm{H}, \mathrm{s}, 3^{\prime \prime \prime}-\mathrm{CH}_{3}\right)\end{array}$ & $\begin{array}{l}6.37(\mathrm{~d}, J=10.3) \\
5.66(\mathrm{~d}, J=10.3) \\
1.47(6 \mathrm{H}, \mathrm{s}) \\
6.10(\mathrm{br}, \mathrm{OH}) \\
5.51(\mathrm{br}, \mathrm{OH})\end{array}$ \\
\hline
\end{tabular}

Values in $(\delta) \mathrm{ppm}$. The coupling constants $(J)$ in parentheses are in $\mathrm{Hz}$. All signals correspond to $\mathrm{l} \mathbf{H}$, unless otherwise stated. a) Assignments may be reversed.

Table 6. ${ }^{13} \mathrm{C}-\mathrm{NMR}$ Data for the New Pyranoxanthones in $\mathrm{CDCl}_{3}$

\begin{tabular}{|c|c|c|c|c|}
\hline & 13 & 14 & 15 & 16 \\
\hline$C-1$ & $160.25(\mathrm{~s})$ & $160.65(\mathrm{~s})$ & $158.49(\mathrm{~s})$ & $160.47(\mathrm{~s})$ \\
\hline C-2 & $111.69(\mathrm{~s})$ & $108.20(\mathrm{~s})$ & $109.06(\mathrm{~s})$ & $108.81(\mathrm{~s})$ \\
\hline C-3 & $158.14(\mathrm{~s})$ & $158.20(\mathrm{~s})$ & $160.55(\mathrm{~s})$ & $162.18(\mathrm{~s})$ \\
\hline C- 4 & $100.97(\mathrm{~s})$ & $99.90(\mathrm{~s})$ & $105.55(\mathrm{~s})$ & 94.48 (d) \\
\hline C-4a & $149.84(\mathrm{~s})$ & -a) $^{a}$ & $152.64(\mathrm{~s})$ & $152.96(\mathrm{~s})$ \\
\hline$C-5$ & $132.27(\mathrm{~s})$ & $132.31(\mathrm{~s})$ & $132.28(\mathrm{~s})$ & $131.96(\mathrm{~s})$ \\
\hline C-6 & $144.51(\mathrm{~s})$ & $144.75(\mathrm{~s})$ & $144.55(\mathrm{~s})$ & $144.65(\mathrm{~s})$ \\
\hline C-7 & $117.60(\mathrm{~s})$ & $117.76(\mathrm{~s})$ & $117.62(\mathrm{~s})$ & $117.65(\mathrm{~s})$ \\
\hline C- 8 & $113.51(\mathrm{~d})$ & $113.48(\mathrm{~d})$ & $113.44(\mathrm{~d})$ & $113.57(\mathrm{~d})$ \\
\hline C-8a & $114.75(\mathrm{~s})$ & -a) $^{a}$ & $114.50(\mathrm{~s})$ & $114.65(\mathrm{~s})$ \\
\hline C-9 & $180.32(\mathrm{~s})$ & $180.43(\mathrm{~s})$ & $180.68(\mathrm{~s})$ & $180.25(\mathrm{~s})$ \\
\hline C-9a & $102.82(\mathrm{~s})$ & $102.67(\mathrm{~s})$ & $103.01(\mathrm{~s})$ & $103.28(\mathrm{~s})$ \\
\hline C-10a & $144.99(\mathrm{~s})$ & $144.99(\mathrm{~s})$ & $145.26(\mathrm{~s})$ & $145.11(\mathrm{~s})$ \\
\hline$C-1^{\prime}$ & $21.23(\mathrm{t})$ & $23.13(\mathrm{t})$ & $21.62(\mathrm{t})$ & $21.42(\mathrm{t})$ \\
\hline $\mathrm{C}-2^{\prime}$ & $122.14(\mathrm{~d})$ & 86.52 (d) & $121.51(\mathrm{~d})^{b)}$ & $121.36(\mathrm{~d})^{b)}$ \\
\hline C- $3^{\prime}$ & $131.46(\mathrm{~s})$ & $144.30(\mathrm{~s})$ & $135.30(\mathrm{~s})$ & $136.08(\mathrm{~s})$ \\
\hline \multirow{3}{*}{$3^{\prime}-\mathrm{CH}_{3}$} & & $112.84(\mathrm{t})$ & & \\
\hline & $25.81(\mathrm{q})$ & $19.64(\mathrm{q})$ & $25.85(\mathrm{q})$ & $25.82(\mathrm{q})$ \\
\hline & $17.91(\mathrm{q})$ & & $17.94(\mathrm{q})$ & $17.90(\mathrm{q})$ \\
\hline$C-1^{\prime \prime}$ & $121.48(\mathrm{~d})$ & $121.36(\mathrm{~d})$ & $121.85(\mathrm{~d})$ & $121.18(\mathrm{~d})^{b)}$ \\
\hline $\mathrm{C}-2^{\prime \prime}$ & $130.86(\mathrm{~d})$ & 130.99 (d) & $130.83(\mathrm{~d})$ & $130.93(\mathrm{~d})$ \\
\hline C- $3^{\prime \prime}$ & $78.87(\mathrm{~s})$ & $78.98(\mathrm{~s})$ & $78.75(\mathrm{~s})$ & $78.89(\mathrm{~s})$ \\
\hline $3^{\prime \prime}-\mathrm{CH}_{3}$ & $28.20(\mathrm{q} \times 2)$ & $28.17(q \times 2)$ & $28.48(\mathrm{q} \times 2)$ & $28.46(q \times 2)$ \\
\hline$C-1^{\prime \prime \prime}$ & $115.52(\mathrm{~d})$ & $115.37(\mathrm{~d})$ & $21.96(t)$ & \\
\hline $\mathrm{C}-2^{\prime \prime \prime}$ & $126.82(\mathrm{~d})$ & $126.76(d)$ & $121.55(\mathrm{~d})^{b)}$ & \\
\hline C- $3^{\prime \prime \prime}$ & $77.95(\mathrm{~s})$ & $78.63(\mathrm{~s})$ & $134.00(\mathrm{~s})$ & \\
\hline \multirow[t]{2}{*}{$3^{\prime \prime \prime}-\mathrm{CH}_{3}$} & $28.45(q \times 2)$ & $28.44(q \times 2)$ & $25.85(\mathrm{q})$ & \\
\hline & & & $17.92(q)$ & \\
\hline
\end{tabular}

Values in $(\delta)$ ppm. a) Because of the small quantity obtained, these quarternary carbon signals could not be assigned. b) Assignments may be reversed.

carbon, and AB-type doublets at $\delta 6.44$ and 5.72 (each $1 \mathrm{H}, J=9.9 \mathrm{~Hz}$ ), indicating the presence of a dimethylpyran ring system in the molecule. In the HMBC spectrum, one of the methylene proton signals of prenyl moieties at $\delta_{\mathrm{H}}$ 3.46 showed $\mathrm{C}-\mathrm{H}$ long-range correlations with the carbon signals at $\delta_{\mathrm{C}} 158.49(\mathrm{C}-1), 109.06(\mathrm{C}-2)$, and $160.55(\mathrm{C}-3)$. The other one at $\delta_{\mathrm{H}} 3.60$ was correlated with carbon signals at $\delta_{\mathrm{C}} 152.64(\mathrm{C}-4 \mathrm{a}), 105.55(\mathrm{C}-4)$, and $160.55(\mathrm{C}-3)$. These results suggested the two prenyl moieties to be located at

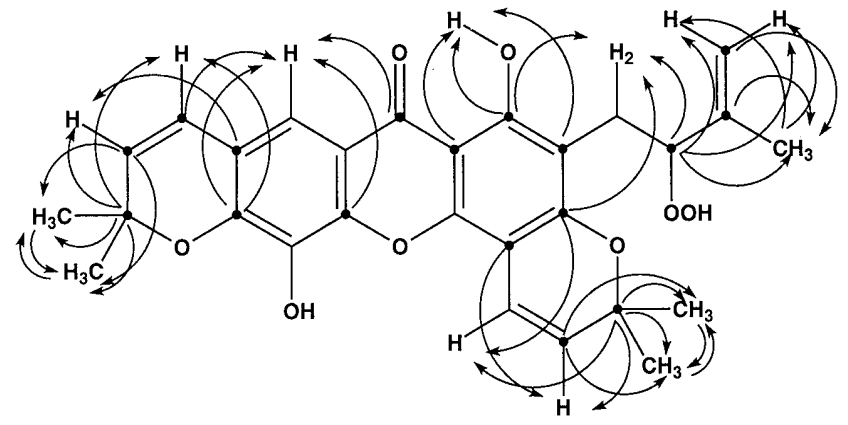

Fig. 7. $\mathrm{C}-\mathrm{H}$ Long-Range Correlations in the $\mathrm{HMBC}$ Spectrum of Latisxanthone-B (14) in $\mathrm{CDCl}_{3}$

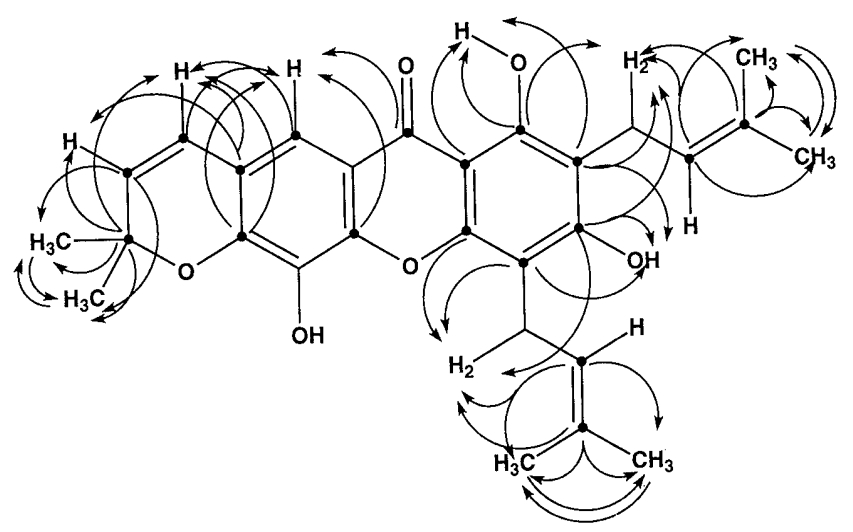

Fig. 8. C-H Long-Range Correlations in the HMBC Spectrum of Latisxanthone- $\mathrm{C}$ (15) in $\mathrm{CDCl}_{3}$

C-2 and C-4, respectively. The presence of a dimethylpyran ring fused with the 1,3,5,6-tetraoxygenated xanthone nucleus at $\mathrm{C}-6$ and $\mathrm{C}-7$ was indicated by $\mathrm{C}-\mathrm{H}$ long-range correlations between a $1 \mathrm{H}$ doublet at $\delta_{\mathrm{H}} 6.44\left(\mathrm{H}-1^{\prime \prime}\right)$ and carbon signals at $\delta_{\mathrm{C}} 113.44(\mathrm{C}-8), 117.62(\mathrm{C}-7)$, and 144.55 $(\mathrm{C}-6)$, together with an NOE enhancement between $\mathrm{H}-1^{\prime \prime}$ $(\delta 6.44)$ and H-8 $(\delta 7.48)$ signals. From the aforementioned results and the $\mathrm{HMBC}$ results shown by arrows in Fig. 8, the structure of latisxanthone-C was concluded to be $\mathbf{1 5}$.

Structure of Latisxanthone-D (16) Latisxanthone-D 
(16) was isolated as a pale yellow oil, $\mathrm{C}_{23} \mathrm{H}_{22} \mathrm{O}_{6}$. The UV absorptions and IR bands (see Experimental) suggested the presence of a xanthone skeleton in the molecule. The ${ }^{1} \mathrm{H}-\mathrm{NMR}$ spectrum showed a similar signal pattern to that of 15, except for the appearance of a higher-field sharp $1 \mathrm{H}$ singlet at $\delta 6.42$ in place of a set of signals assignable to one of two prenyl side chains $\left[-\mathrm{CH}_{2} \mathrm{CH}=\mathrm{C}\left(\mathrm{CH}_{3}\right)_{2}\right]$ in the spectrum of 15. In the $\mathrm{HMBC}$ spectrum, the presence of a prenyl moiety at C-2 was suggested by a significant $\mathrm{C}-\mathrm{H}$ three- or two-bond correlation between a hydrogenbonded proton at $\delta_{\mathrm{H}} 13.32$ and a carbon at $\delta_{\mathrm{C}} 108.81$ (C-2), which was also related to the methylene protons $\left(\mathrm{H}-1^{\prime}, \delta_{\mathrm{H}} 3.40\right)$ on the prenyl moiety. Other long-range correlations observed are shown by arrows in Fig. 9. Based on these results, we assigned structure 16, corresponding to one of the deprenylated derivatives of 15 , to latisxanthone-D.

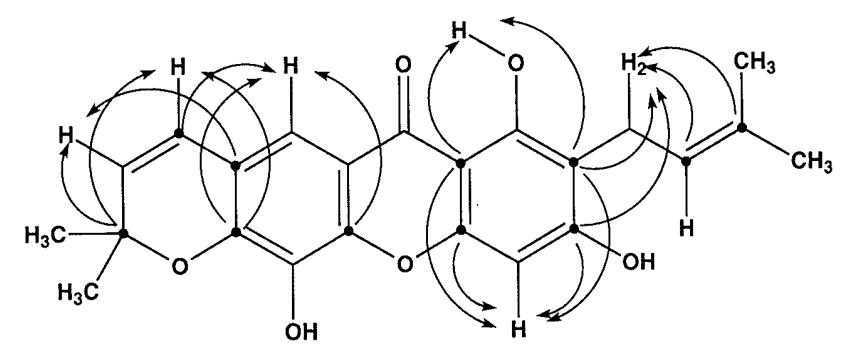

Fig. 9. C-H Long-Range Correlations in the HMBC Spectrum of Latisxanthone-D (16) in $\mathrm{CDCl}_{3}$<smiles>CC1(C)C=Cc2cc3c(=O)c4c(O)c5c(cc4oc3cc2O1)OC(C)(C)C=C5</smiles>

23<smiles>CC1(C)C=Cc2c(c(O)cc3oc4cc(O)cc(O)c4c(=O)c23)O1</smiles>

26<smiles>O=C(c1ccc(O)c(O)c1)c1c(O)cc(O)cc1O</smiles>

27

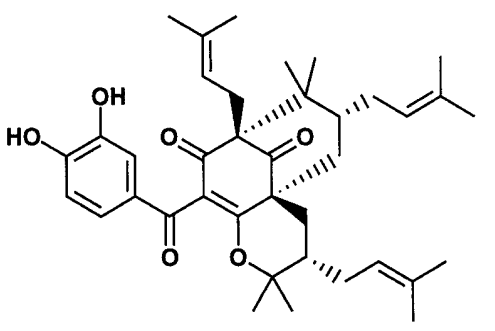

Other compounds isolated from the EtOH extract were characterized as ugaxanthone (8), $\left.{ }^{5}\right) 1,3,6,7$-tetrahydroxy8-(3-methylbut-2-enyl)xanthone (12), ${ }^{6}$ isoprenylxanthone (17), ${ }^{9)}$ pancixanthone-A $(\mathbf{1 8}),{ }^{2)}$ 1,3,5-trihydroxyxanthone (19), ${ }^{10)}$ 1,5-dihydroxyxanthone $(\mathbf{2 0}),{ }^{11)}$ gentisein $(\mathbf{2 1}),{ }^{12)}$ 1,3,7-trihydroxy-2-(3-methyl-2-butenyl)xanthone (22), ${ }^{13)}$ pyranojacereubin (23), ${ }^{14)}$ jacareubin $(\mathbf{2 4}),{ }^{9}$ xanthone V1 (25), ${ }^{15)}$ toxyloxanthone B (26), ${ }^{16,17)}$ maclurin $(\mathbf{2 7}),{ }^{18)}$ isogarcinol (28), ${ }^{19,20)}$ 5-hydroxy-7-methoxy-2-pentylchromone (29), ${ }^{21)}$ and GB-la (30), ${ }^{22)}$ by comparisons of the ${ }^{1} \mathrm{H}-\mathrm{NMR}, \mathrm{IR}, \mathrm{UV}, \mathrm{MS}$, and $[\alpha]_{\mathrm{D}}$ data with those reported in the literature. ${ }^{2,5,6,9-22)}$

\section{Experimental}

Melting points were measured on a micromelting point hot-stage apparatus (Yanagimoto). ${ }^{1} \mathrm{H}-$ and ${ }^{13} \mathrm{C}-\mathrm{NMR}, \mathrm{HMQC}$, and $\mathrm{HMBC}$ $(J=8 \mathrm{~Hz})$ spectra were recorded on an A-400 or A-600 (JEOL) spectrometer. Chemical shifts are shown in $\delta$ values (ppm) with tetramethylsilane (TMS) as an internal reference. All mass spectra were taken under EI conditions, unless otherwise stated, using an M-80 (Hitachi) spectrometer having a direct inlet system. UV spectra were recorded on a UVIDEC-610C double-beam spectrophotometer (JASCO) in $\mathrm{MeOH}$, IR spectra on an IR-230 (JASCO) in $\mathrm{CHCl}_{3}$, and optical rotations on a DIP-370 (JASCO) in $\mathrm{CHCl}_{3}$ at $25^{\circ} \mathrm{C}$. Preparative TLC was done on Kieselgel $60 \mathrm{~F}_{254}$ (Merck).

Plant Materials The plant materials used in this study, Garcinia assigu LantB., Garcinia dulcis (Roxb.) Kurz., and Garcinia latissima Mı. (Guttiferae) were collected in Central Province of Papua New Guinea. Voucher specimens have been deposited at the herbarium of the University of Papua New Guinea.

Isolation and Separation of Garcinisidone-A (1), Assiguxanthone-A (3),<smiles>CCC1(C)C=Cc2c(c(P)c3oc4c(O)c(O)ccc4c(=O)c3c2O)O1</smiles><smiles></smiles><smiles>CCCCCc1cc(=O)c2c(O)cc(O)cc2o1</smiles>

29<smiles>O=C1CC(c2ccc(O)cc2)Oc2c(O)c(O)cc(O)c21</smiles> 
and -B (9) from $G$. assigu The dried stem bark (560 g) of $G$. assigu was extracted with EtOH under reflux. The EtOH extract was evaporated under reduced pressure to give an oily residue, which was fractionated with hexane, $\mathrm{CH}_{2} \mathrm{Cl}_{2}$, EtOAc, $\mathrm{CH}_{2} \mathrm{Cl}_{2}-\mathrm{MeOH}$ (3:1), and $\mathrm{MeOH}$. The hexane-soluble portion was subjected to silica gel chromatography eluted with hexane-acetone $(9: 1,17: 3,4: 1,7: 3,1: 1)$, acetone, $\mathrm{CH}_{2} \mathrm{Cl}_{2}-$ $\mathrm{MeOH}(3: 1)$, and $\mathrm{MeOH}$, successively. The hexane-acetone $(4: 1)$ eluate was further subjected to preparative TLC with hexane-acetone (4:1) and benzene-MeOH $(19: 1)$ as developing solvents to obtain garcinisidone-A (1) $(2.5 \mathrm{mg})$. The $\mathrm{CH}_{2} \mathrm{Cl}_{2}$-soluble portion was subjected to silica gel column chromatography. Successive elution with hexane EtOAc $(9: 1,4: 1,7: 3,3: 2,1: 1,3: 7)$, EtOAc, acetone, $\mathrm{CH}_{2} \mathrm{Cl}_{2}-\mathrm{MeOH}$ $(3: 1)$, and $\mathrm{MeOH}$ gave ten fractions. Each fraction was further subjected to silica gel column chromatography and preparative TLC with appropriate combinations of hexane, benzene, $\mathrm{CHCl}_{3}$, iso- $\mathrm{Pr}_{2} \mathrm{O}$, EtOAc, acctone, and $\mathrm{MeOH}$ as developing solvents to give the following compounds. From the hexane-EtOAc (7:3) fraction: toxyloxanthone B (26) $(4.0 \mathrm{mg})$. From the hexane-EtOAc $(1: 1)$ fraction: assiguxanthone-A (3) $(5.3 \mathrm{mg})$ and 1,3,5-trihydroxyxanthone (19) (2.0 mg). From the hexane-EtOAc (3:7) fraction: assiguxanthone-B (9) (1.4 mg), 1,3,6,7 tetrahydroxy-8-(3-methylbut-2-enyl)xanthone (12) (1.5 mg) and maclurin (27) $(9.8 \mathrm{mg})$. The EtOAc-soluble portion was treated in the same manner as the hexane-soluble portion described above. The hexane-acetone $(9: 1)$ eluate was subjected to silica gel column chromatography with a gradient of hexane and iso- $\mathrm{Pr}_{2} \mathrm{O}$, and further preparative TLC with hexane EtOAc $(9: 1)$ and hexane- $\mathrm{CHCl}_{3}(1: 1)$ to obtain pancixanthone-A (18) (2.6 mg) and I,5-dihydroxyxanthone (20) $(4.6 \mathrm{mg})$.

Garcinisidone-A (1): Pale yellow oil. UV $\lambda_{\max } \mathrm{nm}: 206,226$ (sh), 280 315. IR $v_{\max } \mathrm{cm}^{-1}: 3527,3300($ br), 1668, 1624, 1267, 1153. MS $\mathrm{m} / \mathrm{z}$ $(\%): 426\left(\mathrm{M}^{+}, 100\right), 370(56), 355(24), 339$ (14), $327(16), 315(38), 31$ (13), 299 (13), 273 (14), 219 (16), 217 (21), 191 (15). HR-MS Calcd for $\mathrm{C}_{24} \mathrm{H}_{26} \mathrm{O}_{7}: 426.1676$. Found: 426.1661. Differential NOE: irradiation of $8-\mathrm{OCH}_{3}(\delta 3.66)$ gave $3 \%$ NOE at $\mathrm{H}-2^{\prime}(\delta 5.08)$ and $2 \%$ NOE at H-1 $(\delta 3.33)$; irradiation of $\mathrm{H}-4(\delta 6.26)$ gave $2 \%$ NOE at $\mathrm{H}-6(\delta 6.65)$; irradiation of H-6 $(\delta 6.65)$ gave $1 \%$ NOE at $\mathrm{H}-4(\delta 6.26)$

$O$-Methylation of 1 A mixture of $1(2.5 \mathrm{mg})$, anhydrous $\mathrm{K}_{2} \mathrm{CO}_{3}$ $(4.0 \mathrm{mg})$ and methyl iodide $(5.5 \mu \mathrm{l})$ in acetone $(1.0 \mathrm{ml})$ was stirred overnight. $\mathrm{K}_{2} \mathrm{CO}_{3}$ was filtered off and the filtrate was subjected to preparative TLC [hexane-acetone $(4: 1)$ ] to give a colorless oil (2 $2.4 \mathrm{mg}$ ). 2: Colorless oil. UV $\lambda_{\max }$ nm: 210,223 (sh), 268, 283 (sh). IR $v_{\max } \mathrm{cm}^{-1}: 1730,1605,1257,1143$. MS $m / z(\%): 468\left(\mathrm{M}^{+}, 100\right), 453$ $(51), 437$ (31), $397(11), 371$ (60), 247 (31), 221 (31), $205(57), 191$ (51), $175(40)$. Differential NOE: irradiation of $3-\mathrm{OCH}_{3}(\delta 3.88)$ gave $16 \%$ NOE at $\mathrm{H}-4(\delta 6.83)$ and $1 \% \mathrm{NOE}$ at $3^{\prime}-\mathrm{CH}_{3}(\delta 1.68)$; irradiation of $1-\mathrm{OCH}_{3}(\delta 3.66)$ gave $3,2,2$, and $4 \%$ NOE at H-2 $(\delta 5.01), 3^{\prime}-\mathrm{CH}_{3}(\delta$ $1.68), 3^{\prime \prime}-\mathrm{CH}_{3}(\delta 1.56)$, and $3^{\prime \prime}-\mathrm{CH}_{3}(\delta 1.74)$, respectively; irradiation of $7-\mathrm{OCH}_{3}(\delta 3.80)-16 \%$ NOE at $\mathrm{H}-6(\delta 7.02)$ and $2 \% \mathrm{NOE}$ at $8-\mathrm{OCH}_{3}$ $(\delta 3.69)$; irradiation of $8-\mathrm{OCH}_{3}(\delta 3.69)-1,2,1$, and $1 \% \mathrm{NOE}$ at $7-\mathrm{OCH}_{3}$ $(\delta 3.80), \mathrm{H}-2^{\prime \prime}(\delta 5.01), \mathrm{H}-1^{\prime \prime}(\delta 3.34)$, and $3^{\prime \prime}-\mathrm{CH}_{3}(\delta 1.74)$, respectively; irradiation of $\mathrm{H}-4(\delta 6.83)$ gave $2 \%$ NOE at $\mathrm{H}-6(\delta 7.02)$ and $8 \%$ NOE at $3-\mathrm{OCH}_{3}(\delta 3.88)$; irradiation of $\mathrm{H}-6(\delta 7.02)$ gave $1 \%$ NOE at $\mathrm{H}-4$ $(\delta 6.83)$ and $8 \%$ NOE at $7-\mathrm{OCH}_{3}(\delta 3.80)$.

Assiguxanthone-A (3): Pale yellow powder. UV $\lambda_{\max }$ nm: 204,252 , 283, 327. IR $v_{\text {max }} \mathrm{cm}^{-1}: 3545,3423,3200$ (br), 1647, 1589. MS $m / z(\%)$ $328\left(\mathrm{M}^{+}, 40\right), 313$ (100), 298 (19), 285 (24), 273 (17), 260 (20), 257 (11) 138 (18). HR-MS Calcd for $\mathrm{C}_{18} \mathrm{H}_{16} \mathrm{O}_{6}: 328.0945$. Found: 328.0934

Assiguxanthone-B (9): Yellow powder. UV $\lambda_{\max } \mathrm{nm:} 206,238,259$ 321, 368. IR $v_{\max } \mathrm{cm}^{-1}: 3200(\mathrm{br}), 1645,1614$. MS $m / z(\%): 328\left(\mathrm{M}^{+}\right.$ 46), 313 (28), 311 (17), 285 (79), 273 (100), 260 (14), 245 (9), 201 (10). HR-MS Calcd for $\mathrm{C}_{18} \mathrm{H}_{16} \mathrm{O}_{6}: 328.0945$. Found: 328.0944 .

$\boldsymbol{O}$-Methylation of 9 with Diazomethane A large excess of etherea diazomethane was added to a methanolic solution $(20 \mathrm{ml})$ of $9(1.4 \mathrm{mg})$ and the mixture was left overnight at room temperature. The solven was evaporated, and the residue was purified by preparative TLC with hexane-acetone $(4: 1)$ to give $\mathbf{1 0}$ almost quantitatively: Colorless oil. UV $\lambda_{\max }$ nm: 205, 244, 262, 298 (sh), 319, 360. IR $v_{\max } \mathrm{cm}^{-1}: 3200$ (br), 1647, 1608, 1581. MS $m / z(\%): 370\left(\mathrm{M}^{+}, 49\right), 355$ (23), 327 (76), 315 (100), $295(8), 269(9), 229$ (6), 219 (5), 203 (5). Differential NOE: ir radiation of $3-\mathrm{OCH}_{3}(\delta 3.92)$ gave $23 \% \mathrm{NOE}$ at $\mathrm{H}-4(\delta 6.41)$; irradiation of $6-\mathrm{OCH}_{3}(\delta 4.01)$ gave $10 \%$ NOE at $\mathrm{H}-5(\delta 6.86)$; irradiation of $7-\mathrm{OCH}_{3}(\delta 3.99)$ gave $25 \% \mathrm{NOE}$ at $\mathrm{H}-8(\delta 7.58)$

Isolation and Separation of Dulxanthone-A (4), -B (6), -C (7), and -D (11) from $\boldsymbol{G}$. dulcis The dried stem bark $(1.5 \mathrm{~kg})$ of $G$. dulcis was treated in the same manner as described above. The $\mathrm{CH}_{2} \mathrm{Cl}_{2}$-soluble portion
$(880 \mathrm{mg}$ ) was subjected to silica gel chromatography with hexane-EtOAc $(9: 1,17: 3,4: 1,7: 3,3: 2,3: 7)$, EtOAc, $\mathrm{CH}_{2} \mathrm{Cl}_{2}-\mathrm{MeOH}(3: 1)$, and $\mathrm{MeOH}$, successively. The hexane-EtOAc $(4: 1)$ eluate was further subjected repeatedly to silica gel column chromatographies and preparative TLC with appropriate combinations of hexane, $\mathrm{CH}_{2} \mathrm{Cl}_{2}$, acetone, EtOAc $\mathrm{CHCl}_{3}$, and $\mathrm{MeOH}$ as developing solvents to obtain dulxanthone-C (7) $(4.4 \mathrm{mg})$. The EtOAc-soluble portion $(4.82 \mathrm{~g})$ was subjected to silica gel chromatography with hexane-acetone $(4: 1,3: 1,7: 3,3: 2,1: 1,3: 7)$, acetone, $\mathrm{CH}_{2} \mathrm{Cl}_{2}-\mathrm{MeOH}(3: 1)$, and $\mathrm{MeOH}$, successively. Each fraction was further subjected to silica gel column and preparative TLC with appropriate combinations of hexane, $\mathrm{CH}_{2} \mathrm{Cl}_{2}$, acetone, EtOAc, $\mathrm{CHCl}_{3}$, and $\mathrm{MeOH}$ as developing solvents. From the hexane-acetone (3:1) eluate: dulxanthone-A (4) (8.8 mg), dulxanthone-B (6) (5.9 $\mathrm{mg}$ ), dulxanthone-D (11) (1.0 mg), xanthone V1 (25) $(9.0 \mathrm{mg}), 1,3.7$ trihydroxy-2-(3-methyl-2-butenyl)xanthone $(\mathbf{2 2})(1.7 \mathrm{mg})$ and toxyloxanthone B (26) $(1.0 \mathrm{mg})$. From the hexane-acetone $(7: 3)$ eluate: ugaxanthone (8) (1.9 mg), jacareubin (24) $(3.9 \mathrm{mg})$, gentisein $(\mathbf{2 1})(2.0 \mathrm{mg})$ From the hexane-acetone $(3: 2)$ eluate : isoprenylxanthone $(\mathbf{1 7})(4.6 \mathrm{mg})$. From the hexane-acetone ( $1: 1)$ eluate: GB-1a (30) $(140.3 \mathrm{mg})$

Dulxanthone-A (4): Yellow powder. UV $\lambda_{\max }$ nm: 236 (sh), 253, 285, 328. IR $v_{\max } \mathrm{cm}^{-1}: 3545(\mathrm{br}), 1645,1589$. MS $m / z(\%): 342\left(\mathrm{M}^{+}, 67\right)$, 327 (100), 313 (10), 297 (13), 286 (65), 274 (52), 264 (22), 257 (29), 245 (22), 229 (6), 201 (11), 157 (10), 152 (40). HR-MS Calcd for $\mathrm{C}_{19} \mathrm{H}_{18} \mathrm{O}_{6}$ 342.1102. Found: 342.1105 . Differential NOE: irradiation of the $3-\mathrm{OCH}_{3}$ ( $\delta 3.96)$ gave $4 \%$ NOE at $\mathrm{H}-2(\delta 6.41)$.

$\boldsymbol{O}$-Methylation of 4 with Diazomethane A methanolic solution $(20 \mathrm{ml})$ of $4(2.1 \mathrm{mg})$ was treated in the same manner as described above for the $O$-methylation of $\mathbf{9}$ to give 5 almost quantitatively: Yellow powder. UV $\lambda_{\max } \mathrm{nm}: 242,257$ (sh), 283, 318, 360. IR $v_{\max } \mathrm{cm}^{-1}: 3595$ (br), 1645, 1599, 1572. MS m/z (\%): $370\left(\mathrm{M}^{+}, 98\right), 355(100), 339$ (10), $315(21)$, 302 (64), 299 (5), 293 (5), 278 (8), 272 (12), 269 (7), 257 (11), 227 (6), $177(6), 165(5)$. Differential NOE: irradiation of 3-OCH $(\delta 3.92)$ gave $23 \%$ NOE at $\mathrm{H}-2(\delta 6.38)$; irradiation of $6-\mathrm{OCH}_{3}(\delta 4.01)$ gave $12 \%$ $\mathrm{NOE}$ at $\mathrm{H}-7(\delta 6.98)$; irradiation of $5-\mathrm{OCH}_{3}(\delta 4.00)$ gave no NOE at any proton signal.

Dulxanthone-B (6): Yellow oil. UV $\lambda_{\max } \mathrm{nm}: 236$ (sh), 257, 282 (sh), 327. IR $v_{\max } \mathrm{cm}^{-1}: 3525$ (br), 1635, 1593. MS $m / z(\%): 410\left(\mathrm{M}^{+}, 76\right)$, 395 (14), 379 (11), 367 (100), 355 (89), 339 (30), 321 (14), 311 (22), 299 (15), 297 (22), 285 (49), 257 (12). HR-MS Calcd for $\mathrm{C}_{24} \mathrm{H}_{26} \mathrm{O}_{6}: 410.1728$. Found: 410.1747

Dulxanthone-C (7): Pale yellow powder. UV $\lambda_{\max }$ nm: 236, 254, 284 (sh), 329. IR $v_{\max } \mathrm{cm}^{-1}: 3544(\mathrm{br}), 1645,1622,1601,1577 . \mathrm{MS} m / z(\%)$ : $424\left(\mathrm{M}^{+}, 51\right), 409$ (10), 381 (100), 369 (37), 313 (25). HR-MS Calcd for $\mathrm{C}_{25} \mathrm{H}_{28} \mathrm{O}_{6}: 424.1883$. Found: 424.1881. Differential NOE : irradiation of $3-\mathrm{OCH}_{3}(\delta 3.88)$ gave $27 \%$ NOE at $\mathrm{H}-2(\delta 6.33)$; irradiation of $6-\mathrm{OCH}_{3}(\delta 3.98)$ gave $18 \%$ NOE at $\mathrm{H}-7(\delta 6.72)$; irradiation of $\mathrm{H}-1^{\prime \prime}(\delta$ $4.00)$ gave $9 \%$ NOE at $\mathrm{H}-7(\delta 6.72), 1 \%$ NOE at $\mathrm{H}-2^{\prime \prime}(\delta 5.34)$, and $1 \%$ $\mathrm{NOE}$ at $3^{\prime \prime}-\mathrm{CH}_{3}(\delta 1.74)$; irradiation of $\mathrm{H}^{-1}{ }^{\prime}(\delta 3.50)$ gave $1 \% \mathrm{NOE}$ at $\mathrm{H}-2^{\prime}(\delta 5.25), 9 \% \mathrm{NOE}$ at $3^{\prime}-\mathrm{CH}_{3}(\delta 1.80)$.

Dulxanthone-D (11): Yellow powder. UV $\lambda_{\max } n \mathrm{~nm}: 241,252,312,350$. IR $v_{\max } \mathrm{cm}^{-1}: 3400$ (br), 1647, 1604, 1558. MS $m / z(\%): 342\left(\mathrm{M}^{+}, 39\right)$, 327 (29), 311 (13), 309 (16), 299 (73), 285 (17), 284 (18), 271 (16), 257 (10), 245 (7), 229 (6), 216 (6), 203 (6), 187 (8). HR-MS Calcd for $\mathrm{C}_{19} \mathrm{H}_{18} \mathrm{O}_{6}: 342.1102$. Found: 342.1109 . Differential NOE: irradiation of $7-\mathrm{OCH}_{3}(\delta 3.81)$ gave $3 \%$ NOE at $\mathrm{H}-\mathrm{I}^{\prime}(\delta 4.08)$.

Isolation and Separation of Latisxanthone-A (13), -B (14), -C (15) and -D (16) from $G$. latissima The dried stem bark $(550 \mathrm{~g})$ of $G$. latissima was also treated in the same manner as described above. The hexanesoluble portion $(5 \mathrm{~g})$ was subjected to silica gel column chromatography with hexane-acetone $(10: 1,4: 1,2: 1,1: 1,1: 2)$, acetone, $\mathrm{CH}_{2} \mathrm{Cl}_{2}$ $\mathrm{MeOH}(3: 1)$, and $\mathrm{MeOH}$, successively. Each fraction was further subjected to silica gel column chromatographies and preparative TLC with appropriate combinations of the same solvents as described above. From the hexane--acetone $(4: 1)$ eluate : 5-hydroxy-7-methoxy-2-pentylchromone (29) $(1.8 \mathrm{mg})$. From the hexane-acetone $(1: 1)$ eluate latisxanthone-D (16) $(1.0 \mathrm{mg})$ and $\mathrm{GB}-1 \mathrm{a}(\mathbf{3 0})(6.7 \mathrm{mg})$. The $\mathrm{CH}_{2} \mathrm{Cl}_{2}$ soluble portion $(2.2 \mathrm{~g})$ was subjected to silica gel chromatography eluted with hexane-acetone $(10: 1,4: 1,2: 1,1: 1,1: 2)$, acetone, $\mathrm{CH}_{2} \mathrm{Cl}_{2}$ $\mathrm{MeOH}(3: 1)$, and $\mathrm{MeOH}$, successively. Each fraction was further subjected to silica gel column chromatographies and preparative TLC with appropriate combinations of the same solvents as described above. From the hexane-acetone (2:1) eluate : latisxanthone-A (13) (4.2 $\mathrm{mg}$ ) and latisxanthone-B (14) $(1.0 \mathrm{mg})$. From the hexane-acetone $(1: 1)$ eluate latisxanthone-C (15) (1.0 mg) and pyranojacereubin (23) $(2.3 \mathrm{mg})$. From 
the hexane acetone $(1: 2)$ eluate : isogarcinol $(28)(15.1 \mathrm{mg})$.

Latisxanthone-A (13): Yellow powder. UV $\lambda_{\max }$ nm: 282, 337, 371. IR $v_{\max } \mathrm{cm}^{-1}: 3539(\mathrm{br}), 1635,1583$. MS $m / z(\%): 460\left(\mathrm{M}^{+}, 86\right), 445(100)$, 417 (51), 405 (63), 389 (14), 377 (9), 230 (11), 215 (19), 203 (18), 187 (26). HR-MS Calcd for $\mathrm{C}_{28} \mathrm{H}_{28} \mathrm{O}_{6}: 460.1884$. Found: 460.1877. Differential NOE: irradiation of $\mathrm{H}-8(\delta 7.47)$ gave $8 \%$ NOE at H-1" $(\delta$ 6.42).

Latisxanthone-B (14): Yellow powder. $[\alpha]_{\mathrm{D}}+5^{\circ}(c=0.066)$. UV $\lambda_{\max }$ $\mathrm{nm}: 224(\mathrm{sh}), 280,331,370 . \mathrm{IR} v_{\max } \mathrm{cm}^{-1}: 3734,3545,3384$ (br), 1635, 1583. FAB-MS $m / z(\%): 493[\mathrm{M}+\mathrm{H}]^{+}$. EI-MS $m / z(\%): 476(12), 405$ (100), 391 (16), 248 (14), 203 (15). HR-FAB-MS Calcd for $\mathrm{C}_{28} \mathrm{H}_{29} \mathrm{O}_{8}$ : 493.1863 $[\mathrm{M}+\mathrm{H}]^{+}$. Found: 493.1852. Differential NOE: irradiation of $\mathrm{H}-8(\delta 7.42)$ gave $12 \%$ NOE at H-1" $(\delta 6.38)$.

Latisxanthone-C (15): Pale yellow powder. UV $\lambda_{\max } \mathrm{nm:} 281,337,383$. IR $v_{\max } \mathrm{cm}^{-1}: 3543,3377(\mathrm{br}), 1637,1614,1583$. MS $m / z(\%): 462\left(\mathrm{M}^{+}\right.$, 35), 445 (10), 419 (22), 407 (22), 405 (11), 391 (16), 363 (23), 351 (40), 335 (11), 203 (12), 188 (12). HR-MS Calcd for $\mathrm{C}_{28} \mathrm{H}_{30} \mathrm{O}_{6}: 462.2040$. Found: 462.2036. Differential NOE: irradiation of $\mathrm{H}-1^{\prime \prime}(\delta 6.44)$ gave $10 \%$ NOE at $\mathrm{H}-8(\delta 7.48)$; irradiation of $\mathrm{H}-1^{\prime}(\delta 3.46)$ gave $7 \%$ NOE at $\mathrm{H}-2^{\prime}(\delta 5.29)$ and $10 \%$ NOE at $3^{\prime}-\mathrm{CH}_{3}(\delta 1.85)$; irradiation of $\mathrm{H}-1^{\prime \prime \prime}$ $(\delta 3.60)$ gave $1 \%$ NOE at $3-\mathrm{OH}(\delta 6.43), 4 \%$ NOE at $\mathrm{H}-2^{\prime \prime \prime}(\delta 5.32)$, and $12 \%$ NOE at $3^{\prime \prime \prime}-\mathrm{CH}_{3}(\delta 1.89)$.

Latisxanthone-D (16): Pale yellow oil. UV $\lambda_{\max } \mathrm{nm}: 261$ (sh), 288, 296, 346. IR $v_{\max } \mathrm{cm}^{-1}: 3566,3423$ (br), 1635, 1608, 1583. MS m/z (\%): 394 $\left(\mathrm{M}^{+}, 60\right), 379(42), 351$ (70), 339 (100), 323 (27), 311 (13), 203 (12), 162 (16). HR-MS Calcd for $\mathrm{C}_{23} \mathrm{H}_{22} \mathrm{O}_{6}$ : 394.1414. Found: 394.1398. Differential NOE: irradiation of $\mathrm{H}-8(\delta 7.43)$ gave $11 \%$ NOE at $\mathrm{H}-1^{\prime \prime}$ $(\delta 6.37)$.

Acknowledgements We are grateful to Mr. Pius Piskaut of the Biology Department, University of Papua New Guinea for identification of the plants. We also thank Mr. K. Masuda of Meijo University for measurements of HR-FAB-MS.

\section{References and Notes}

1) A part of this paper was presented at the 116th Annual Meeting of the Pharmaceutical Society of Japan, Kanazawa, March 1996.

2) Ito C., Miyamoto Y., Rao K. S., Furukawa H., Chem. Pharm. Bull., 44, 441-443 (1996).

3) Rao K. S., Int. J. Pharmacogn., 34, $223-225$ (1996). ${ }^{4)}$
4) In this paper, as the scientific names of two Garcinia species had not been assigned, Garcinia species I and II were used tentatively. Garcinia species I and II have now been identified as Garcinia dulcis (RoxB.) Kurz. and Garcinia latissima (MrQ.), respectively.

5) Locksley H. D., Moore I., Scheinmann F., J. Chem. Soc. (C), 1966, 2265-2269.

6) Ishiguro K., Nakajima M., Fukumoto H., Isoi K., Phytochemistry, 38, 867-869 (1995).

7) Monache G. D., Botta B., de Mello J. F., de Barros Coelho J. S., Menichini F., J. Nat. Prod., 47, 620-625 (1984).

8) Hano Y., Matsumoto Y., Shinohara K., Sun J.-Y., Nomura T., Planta Med., 57, 172-175 (1991).

9) Scheinmann F., Sripong N.-A., Phytochemistry, 10, 1331-1333 (1971).

10) Locksley H. D., Murray I. G., J. Chem. Soc. (C), 1971, 13321340.

11) Rocha L., Marston A., Kaplan M. A. C., Stoeckli-Evans H., Thull U., Testa B., Hostettmann K., Phytochemistry, 36, 1381-1385 (1994).

12) Kitanov G., Achtardjiev C., Pharmazie, 34, 447-448 (1979).

13) Harrison L. J., Leong L.-S., Sia G.-L., Sim K.-Y., Tan H. T.-W., Phytochemistry, 33, 727-728 (1993).

14) Waterman P. G., Crichton E. G., Phytochemistry, 19, 2723-2726 (1980).

15) Botta B., Monache G. D., Monache F. D., Bettolo G. B. M., Menichini F., Phytochemistry, 25, 1217-1219 (1986)

16) Chen M.-T., Chen C.-M., Heterocycles, 23, 2543-2548 (1985).

17) Ishiguro K., Fukumoto H., Nakajima M., Iso K., Phytochemistry, 33, $839-840$ (1993).

18) Locksley H. D., Moore I., Scheinmann F., Tetrahedron, 23, 2229-2234 (1967)

19) Krishnamurthy N., Lewis Y. S., Ravindranath B., Tetrahedron Lett., 22, 793-796 (1981).

20) Krishnamurthy N., Ravindranath B., Guru Row T. N., Ven Katesan K., Tetrahedron Lett., 23, 2233-2236 (1982).

21) Jimenez C., Marcos M., Villaverde M. C., Riguera R., Castedo L., Stermitz F., Phytochemistry, 28, $1992-1993$ (1989).

22) Cotterill P. J., Scheinmann F., Stenhouse I. A., J. Chem. Soc., Perkin Trans. I, 1978, 532-539. 